\title{
REVIEW
}

\section{Planktonic food webs: microbial hub approach}

\author{
Louis Legendre ${ }^{1,2, *}$, Richard B. Rivkin ${ }^{3}$ \\ ${ }^{1}$ UPMC Univ Paris 06, UMR 7093, Laboratoire d'Océanographie de Villefranche, 06230 Villefranche-sur-Mer, France \\ ${ }^{2}$ CNRS, UMR 7093, LOV, 06230 Villefranche-sur-Mer, France \\ ${ }^{3}$ Ocean Sciences Centre, Memorial University of Newfoundland, St. John's, Newfoundland A1C 5S7, Canada
}

\begin{abstract}
Our review consolidates published information on the functioning of the microbial heterotrophic components of pelagic food webs, and extends this into a novel approach: the 'microbial hub' (HUB). Crucial to our approach is the identification and quantification of 2 groups of organisms, each with distinct effects on food-web flows and biogeochemical cycles: microbes, which are generally responsible for most of the organic carbon respiration in the euphotic zone, and metazoans, which generally account for less respiration than microbes. The key characteristics of the microbialhub approach are: all heterotrophic microbes are grouped together in the HUB, whereas larger heterotrophs are grouped into a metazoan compartment (METAZ); each food-web flow is expressed as a ratio to community respiration; summary respiration flows through, between, and from the HUB and METAZ are computed using flows from observations or models; both the HUB and METAZ receive organic carbon from several food-web sources, and redirect this carbon towards other foodweb compartments and their own respiration. By using the microbial-hub approach to analyze a wide range of food webs, different zones of the world ocean, and predicted effects of climate change on food-web flows, we conclude that heterotrophic microbes always dominate respiration in the euphotic zone, even when most particulate primary production is grazed by metazoans. Furthermore, climate warming will increase HUB respiration and channeling of primary production toward heterotrophic community respiration and decrease the corresponding METAZ flows. The microbial-hub approach is a significant evolution and extension of the microbial loop and food web, and provides a new, powerful tool for exploring pelagic community metabolism.
\end{abstract}

KEY WORDS: Plankton · Food webs $\cdot$ Heterotrophic microbes $\cdot$ Microbial hub $\cdot$ Protozoa $\cdot$ Metazoa Respiration Resale or republication not permitted without written consent of the publisher

\section{INTRODUCTION}

In the early 1970s, it was concurrently proposed by investigators in North America and Russia that marine autotrophic and heterotrophic microbes were important and, at times, the dominant components of watercolumn production and respiration (e.g. Hobbie et al. 1972, Vinogradov et al. 1972, Pomeroy 1974). Increasing information on the microbial component of the marine pelagic food web (e.g. Sieburth et al. 1978, Sorokin 1981, Williams 1981, Sherr \& Sherr 1988) led to the emergence of the 'microbial loop' conceptual model (initially described in Azam et al. 1983 and Gray et al. 1984, see also the historical review of Sherr \&
Sherr 2008a). In that conceptual model, dissolved organic matter (DOM) released by autotrophic and heterotrophic plankton was utilized by heterotrophic bacteria. Both heterotrophic and autotrophic bacteria (in the above 2 papers, autotrophic bacteria were called cyanobacteria) were ingested primarily by small heterotrophic flagellates, and these were, in turn, ingested by other protozoan microzooplankton. Azam et al. (1983) concluded that the 'energy released as DOM is rather inefficiently returned to the main food chain via a microbial loop of bacteria-flagellatesmicrozooplankton'. The microbial loop conceptual model led to a paradigm shift, by assigning key roles to bacteria, flagellates, and other microzooplankton in a 
generalized planktonic food web, where the previously conceptually dominant herbivorous food web (e.g. Ryther 1969) was but one component. The above perspective has inspired extensive research on pelagic food webs and marine biogeochemical fluxes in the subsequent decades. Among other aspects, it led to new diagnostic and predictive models for both planktonic food-web ecology (e.g. Fasham 1985, Moloney \& Field 1991, Anderson \& Ducklow 2001) and marine biogeochemistry (e.g. Le Quéré et al. 2005).

Below, we group the smallest components of the planktonic food web under the generic term 'microbes'. This well known word comes from the Greek 'micros' ( $\mu 1 \kappa \rho \circ \varsigma$, small) and 'bios' ( $\beta 1 \circ \varsigma$, life). We operationally define planktonic microbes as unicellular planktonic organisms and viruses (it is a matter of controversy whether viruses are living organisms). Planktonic microbes cover a wide size range, from viruses to heterotrophic Bacteria and Archaea, phytoplankton cells, heterotrophic and mixotrophic flagellates, and ciliates.

Archaea are present in sometimes high abundances in marine waters (Karner et al. 2001), where they are often enumerated as heterotrophic Bacteria. In this review, we do not consider explicitly the ecological or biogeochemical roles of Archaea. Because an unknown fraction of the food-web flows ascribed to heterotrophic bacteria may be due to Archaea (Herndl et al. 2005, DeLong 2006, Teira et al. 2006, Kirchman et al. 2007), and their roles in biogeochemical transformations are not well documented or parameterized (e.g. Karl 2007), in the model used in this review we have combined Archaea and Bacteria under the functional category of 'heterotrophic bacteria' (or, more simply, 'bacteria').

Heterotrophs in the ocean are often grouped into broad categories (e.g. based on size; bacteria, microzooplankton $<200 \mu \mathrm{m}$, mesozooplankton 0.2 to $2.0 \mathrm{~mm}$, larger animals $>2 \mathrm{~mm}$ ). Frequently, organisms within the broad categories have very different characteristics (physiology, feeding mechanisms, etc.). When the objective of the research is to understand and model food-web interactions or biogeochemical cycles, distinct functional types are often identified, defined and parameterized within the broad categories, based on organisms ecological or biogeochemical functions (e.g. Le Quéré et al. 2005, for plankton functional types). Alternatively, models with objectives other than understanding and representing food-web interactions or biogeochemical cycles used broad categories of organisms without subdividing them into functional types (e.g. Anderson \& Ducklow 2001). Finally, in research where the objective is to compare food webs or ecosystems, another approach is to combine the food-web flows into general indices (e.g. the index of recycling proposed by Jackson \& Eldridge 1992), which are then used for comparing different systems, structures, or conditions. In the present paper, we show that heterotrophic respiration within the euphotic zone (for which there is quantitative information at the scale of the world ocean) provides key information needed for developing a set of operational food-web and biogeochemical indices. These will be referred to as 'summary respiration flows'.

Small heterotrophs, i.e. bacteria and protozoans (flagellates and ciliates), generally account for at least $75 \%$ of respiration in the euphotic zone (Sherr \& Sherr 1996, Robinson \& Williams 2005), whereas metazoans generally account for a smaller fraction of euphoticzone respiration than microbes. Hence, based on estimates or measurements of heterotrophic respiration, it is possible to distinguish 2 groups of organisms, each with different effects on food-web flows and biogeochemical cycles. Below, we develop and quantify the contributions of different groups of organisms to respiration, and use the resulting values to compute summary respiration flows.

In our review, we contrast the ecological and biogeochemical roles of heterotrophic microbes and metazoans in the euphotic zone, and we group all heterotrophic microbes into a 'microbial hub'. The latter has emergent characteristics, and we use the microbialhub approach to explore fundamental marine pelagic community metabolism.

A comprehensive review of the numerous and diverse studies on marine microbial processes that have been published in the last decades is beyond the scope of a single review article (e.g. see Kirchman $2000,2008)$. Instead in the present paper, we identify key processes and concepts, propose a framework that permits the structuring of available information, and use that framework to advance our understanding of food-web functioning and responses to environmental forcing.

\section{PROPOSED APPROACH: THE 'MICROBIAL HUB'}

We propose that, within the planktonic food web, heterotrophic microbes represent a 'microbial hub' (HUB, subscript 'hub'), into which organic carbon is channeled by various food-web processes and from which carbon is redirected towards both $\mathrm{CO}_{2}$ (HUB respiration) and larger heterotrophs (metazoan compartment, METAZ, subscript 'met', comprising all heterotrophs larger than microbes, irrespective of their sizes). Organisms in the METAZ compartment range from small-sized copepods (e.g. Oithona, Metridia and Clausocalanus $<500 \mu \mathrm{m}$ in effective body diameter) to $30 \mathrm{~m}$ long baleen whales. In the context of the present study, the word 'hub' does not refer to 'the central part 
of a circular object', but rather a 'center of activity' or 'focal point'.

Before and since the introduction of the microbial loop concept, numerical models have represented the flows of chemical elements into, within, and out of marine pelagic food webs. Most of these models included both respiration (at least implicitly, through assimilation efficiency coefficients) and feedback flows from metazoans to microbes (through organic detritus and/or dissolved organic carbon, DOC); this was the case in both early (e.g. Vinogradov et al. 1972, Pace et al. 1984, Jumars et al. 1989) and more recent (e.g. Moloney \& Field 1991, Nagata 2000, Anderson \& Ducklow 2001) models. However, most conceptual models that included the microbial loop have represented it without remineralization (i.e. respiration) (e.g. Azam et al. 1983, his Fig. 3, Pomeroy \& Wiebe 1988, their Fig. 1, Cushing 1989, their Fig. 2) or feedback flows from metazoans to microbes (e.g. the last 2 references cited). An exception is the early conceptual model of ZoBell (1946, in Sherr \& Sherr 2008a), which included respiration flows and feedback flows from metazoans to microbes.

In Fig. $1 b$, the microbial-hub approach is applied to the food-web model illustrated in Fig. 1a (see Table 1 for abbreviations and notations used in this review). Although phytoplankton organisms are also classified as microbes, we limited the HUB to heterotrophic microbes, in order to make our approach operational (e.g. Legendre \& Rivkin 2002). The key characteristics of the microbial-hub approach are: (1) all heterotrophic microbes are grouped together in the HUB, whereas larger, heterotrophic organisms are grouped into the METAZ; (2) each food-web flow is expressed as a ratio to community respiration; (3) summary respiration flows through, between, and from the HUB and METAZ are computed using flows derived from observations or obtained with models; (4) both the HUB and METAZ have a dual role in the euphotic zone, i.e. receiving organic carbon from several food-web sources, and redirecting this carbon towards other food-web compartments and towards their own respiration.

The microbial-hub approach allows both distinguishing and assessing the roles of the HUB and METAZ in carbon cycling, e.g. to quantitatively compare pelagic ecosystems and to explore key characteristics of food-web metabolism in changing environments, as we show below. Food-web models (which generally include some of the components of the microbial loop) do not provide directly such information, because they consider a large number of foodweb compartments, and the flows between compartments are of various types. Hence, the microbial-hub approach extends the microbial loop concept. In the present study, the microbial-hub approach will be (a) Food-web model

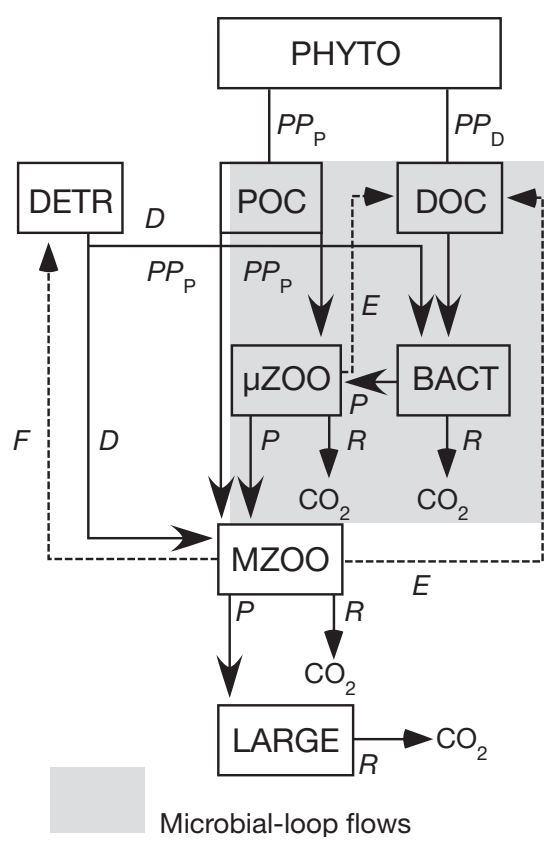

(b) Microbial-hub version of the model

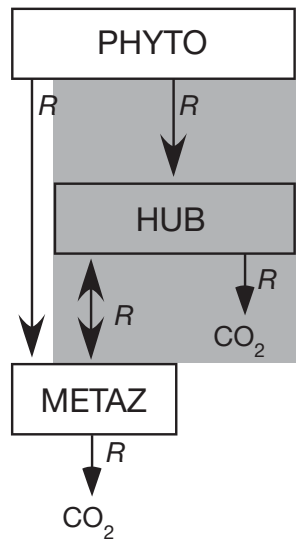

Microbial-hub summary respiration flows
Fig. 1. Schematic representation of the microbial-hub approach, using as an example a food-web model with 7 compartments. (a) Food-web model: (1) particulate organic carbon (POC), produced by phytoplankton (PHYTO); (2) dissolved organic carbon (DOC), from PHYTO and excreted by both microzooplankton ( $\mathrm{ZZOO)}$ and mesozooplankton (MZOO); (3) heterotrophic bacteria (BACT), which use DOC and detrital POC (DETR); (4) $\mu \mathrm{ZOO}$, which consume POC and BACT; (5) MZOO, which consume POC, $\mu Z O O$ and DETR; (6) large animals (LARGE), which consume MZOO or food that is derived from MZOO; and (7) DETR, which comes from metazoans, mostly MZOO. The arrows represent carbon flows into and out of compartments: primary production $\left(P P\right.$, particulate $\left[P P_{\mathrm{P}}\right]$ and dissolved $\left.\left[P P_{\mathrm{D}}\right]\right)$; heterotrophic detritus consumption $(D)$, excretion $(E)$, egestion $(F)$, production $(P)$ and respiration $(R)$. (b) Application of the microbial-hub approach to the model in (a): PHYTO-POC and PHYTO-DOC are merged into PHYTO, $\mu \mathrm{ZOO}$ and BACT make up the microbial hub (HUB), and MZOO are combined with LARGE into the metazoan compartment (METAZ). The arrows represent summary $R$ flows. The HUB consumes PHYTO, receives carbon from METAZ, and redirects the carbon it ingests towards $\mathrm{CO}_{2}$ (respiration) and METAZ. Solid arrows: forward flows; dashed arrows: backward flows; double-headed arrow: net flow possible in both directions

developed theoretically, and then applied to a foodweb model (Fig. 1a) to demonstrate its utility. It will also be applied to selected field data, to demonstrate its general applicability. The microbial-hub approach can be used to synthesize into summary respiration flows the carbon flows derived from any food-web model or from field observations, and analyze, with the summary respiration flows, carbon cycling in food webs.

The underlying concept for the microbial hub can be found in Lindeman (1941), who put bacteria and DOM 
Table 1. Notations for the variables, flows of organic carbon (parameter and modeled flows; italic letters), and subscripts used in the present study

\begin{tabular}{|c|c|}
\hline Notation & Variable, model parameter, model flow \\
\hline$A$ & Assimilation \\
\hline $\mathrm{AE}$ & Assimilation efficiency \\
\hline BACT & Bacteria \\
\hline BGE & Bacterial growth efficiency \\
\hline$D$ & Detritus consumption \\
\hline DETR & Detritus (POC) \\
\hline DOC & Dissolved organic carbon \\
\hline DOM & Dissolved organic matter \\
\hline$I$ & Ingestion \\
\hline E & Excretion \\
\hline$F$ & Egestion \\
\hline GGE & Gross growth efficiency \\
\hline HUB & Microbial hub \\
\hline$L$ & Lysis (viral) \\
\hline LARGE & Large heterotrophs \\
\hline M & Import \\
\hline METAZ & Metazoan heterotrophs \\
\hline MZOO & Mesozooplankton \\
\hline$\mu \mathrm{ZOO}$ & Microzooplankton \\
\hline NGE & Net growth efficiency \\
\hline$P$ & Production (heterotrophic) \\
\hline PER & Percentage of extracellular release \\
\hline PHYTO & Phytoplankton \\
\hline POC & Particulate organic carbon \\
\hline$P P$ & Primary production ${ }^{\mathrm{a}}$ \\
\hline$R$ & Respiration \\
\hline$R_{\text {hub }}$ & HUB $R$ \\
\hline$R_{\text {hub }}\left(P P_{\mathrm{T}}\right)$ & Direct HUB channeling of carbon toward $R_{\mathrm{C}}$ \\
\hline$R_{\text {met }}$ & METAZ $R$ \\
\hline$R_{\text {met }}($ hub) & $\begin{array}{l}\text { Channeling of carbon by HUB toward METAZ } \\
R \text { minus that by METAZ toward HUB } R\end{array}$ \\
\hline$R_{\text {met }}\left(P P_{\mathrm{T}}\right)$ & Direct METAZ channeling of carbon toward $R_{\mathrm{C}}$ \\
\hline$U$ & Uptake \\
\hline$X$ & Export \\
\hline$\tau$ & Turnover time of carbon \\
\hline Subscript & Meaning \\
\hline $\mathrm{b}$ & Bacteria (heterotrophic) \\
\hline hub & Microbial hub \\
\hline large & Large heterotrophs \\
\hline $\mathrm{mz}$ & Mesozooplankton \\
\hline$\mu \mathrm{z}$ & Microzooplankton \\
\hline met & Metazoa \\
\hline $\mathrm{x}$ & Heterotrophic food-web compartment \\
\hline $\mathrm{C}$ & Heterotrophic community \\
\hline $\mathrm{D}$ & Dissolved $(P P)$ \\
\hline $\mathrm{L}$ & Large-sized $(P P)$ \\
\hline DOC & Dissolved organic carbon \\
\hline $\mathrm{P}$ & Particulate $(P P)$ \\
\hline Pmz & $P P_{\mathrm{P}}$ consumed by MZOO \\
\hline $\mathrm{P} \mu \mathrm{z}$ & $P P_{\mathrm{P}}$ consumed by $\mu \mathrm{ZOO}$ \\
\hline $\mathrm{T}$ & Total $(P P)=D+P$ \\
\hline Tmz & $P P_{\mathrm{T}}$ consumed by MZOO \\
\hline $\mathrm{T} \mu \mathrm{z}$ & $P P_{\mathrm{T}}$ consumed by $\mu \mathrm{ZOO}$ \\
\hline
\end{tabular}

(which he called 'ooze'; this term also included organic detritus) at the center of a conceptual carbon flow model of planktonic and benthic food webs in a shallow lake (Fig. 1 in Lindeman 1941). Lindeman (1942) re-published Fig. 1 from Lindeman (1941), but did not include bacteria and DOC in the well-known trophodynamic model he proposed in that 1942 paper. The term 'hub', which was applied by Sobczak (2005) to Fig. 1 in both papers (Lindeman 1941, 1942), was not used in these 2 studies.

In the following sections of the present paper, we review the bases for modeling food webs and comparing food-web compartments in general, develop and discuss a food-web model to illustrate our approach, develop and implement the microbial-hub approach, and apply the microbial-hub approach to model and field results.

\section{COMPONENTS OF A GENERALIZED PLANKTONIC FOOD-WEB MODEL}

\section{Partitioning of ingested carbon among food-web processes}

In Fig. 1a, the organic carbon that enters a food-web compartment (e.g. bacteria, microzooplankton) is partitioned among several output flows (i.e. food-web processes). The sum of the input flows into an individual heterotrophic compartment is generally called ingestion $(I)$. Fig. 2 schematizes how $I$ is partitioned among the compartment's food-web processes. Part of $I$ is assimilated $(A)$ and the remainder is egested as particulate organic carbon (POC), typically in the form of fecal material $(F)$. The flow from a living compartment to detritus (DETR) is $F$. Assimilation is partitioned among heterotrophic production $(P$; i.e. flow from a living compartment to another), heterotrophic respiration $\left(R\right.$; i.e. flow from a living compartment to $\left.\mathrm{CO}_{2}\right)$, and excretion of DOC into the surrounding medium $(E$; i.e. flow from a living compartment to DOC). $D$ refers to the consumption of DETR. These various terms, and others, are examined in more detail in the following paragraphs. $A$ is equivalent to organic carbon demand (i.e. $P+R+E$ ).

The food-web flows defined above and our equations below apply to entire food-web compartments, but not at the levels of individual organisms or taxa. For example, at the level of individual bacteria, lysis by viruses or ingestion by microzooplankton lead to mortality of individual cells (i.e. the individual cells cease to exist), whereas in our model bacterial lysis or consumption by grazers is reflected in a modification of the existing flows from the bacterial compartment. More generally, each food-web compartment is an 
(a) Food ingestion (I) in a generalized food-web compartment

\begin{tabular}{|c|c|c|c|}
\hline \multicolumn{3}{|c|}{ assimilation $(A)$} & \multirow[b]{2}{*}{$\begin{array}{c}\text { egestion } \\
F\end{array}$} \\
\hline \begin{tabular}{|c} 
production \\
$P$
\end{tabular} & \begin{tabular}{|c|} 
respiration \\
$R$
\end{tabular} & $\begin{array}{c}\text { excretion } \\
E\end{array}$ & \\
\hline $\mathrm{NGE}=P / A$ & $\leftarrow(1-N G E)$ & $R+E) / A \rightarrow$ & \\
\hline
\end{tabular}

(b) Food ingestion (I) by protozoa

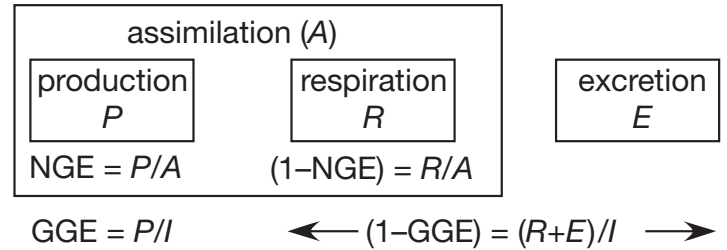

(c) Substrate assimilation $(A)$ or uptake $(U)$ by heterotrophic bacteria $(A=U)$

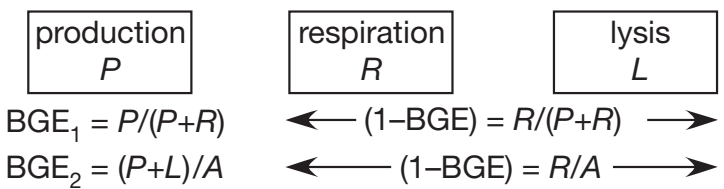

Fig. 2. Partitioning of the organic carbon ingested or assimilated by heterotrophic compartments of the food web, for metazoans, protozoans, and heterotrophic bacteria. (a) In the generalized food-web compartment, which applies to metazoans, $I$ is partitioned between $F$ and $A_{\text {; }}$ the latter is further partitioned among $P, R$, and $E$; net growth efficiency (NGE) and gross growth efficiency (GGE) are defined by reference to $A$ and $I$, respectively, and are linked by assimilation efficiency $(\mathrm{AE}=A / I)$. (b) For protozoans, the partitioning of organic carbon between $F$ and $E$ is poorly characterized; hence, the 2 values are generally combined into $E$. (c) The organic substrates assimilated by bacteria are partitioned between $P$ and $R$ (i.e. $E=0$ ); dissolved organic carbon may be released in the environment following viral lysis, or even through nonviral mechanisms; and there are 2 ways to define bacterial growth efficiency (BGE)

assemblage of organisms and taxa with high diversity, different feeding and growth characteristics, and a variety of biogeochemical roles. For example, bacteria are phylogenetically diverse and show distinct seasonal succession (Fuhrman et al. 2006), biogeographical distributions (Martiny et al. 2006), and nutritional strategies (Cottrell \& Kirchman 2000, Malmstrom et al. 2004, Pernthaler \& Amann 2005). However, although our incomplete knowledge of bacterial phylotypes does not allow associating most of them to specific biogeochemical or ecological functions, some key functional characteristics of bacteria at the community level (e.g. respiration) appear to be independent from bacterial diversity (Langenheder et al. 2005, Reinthaler et al. 2005).
Fig. 2a illustrates, for a generalized food-web compartment (subscript ' $x$ '), the partitioning of $I$ between undigested materials (i.e. $F$ ) and $A$. Assimilation is further partitioned into $P, R$, and $E$ :

$$
I_{\mathrm{x}}=A_{\mathrm{x}}+F_{\mathrm{x}}=\left(P_{\mathrm{x}}+R_{\mathrm{x}}+E_{\mathrm{x}}\right)+F_{\mathrm{x}}
$$

Hence, in this review, $P$ is net rate of $R$ and $E$ (and $F$ ). We define $F$ as the evacuation of ingested organic matter that has not been metabolized by the organisms, but has instead been repackaged as detrital POC (e.g. fecal material). In contrast, $E$ is the release of DOM previously metabolized by organisms (e.g. urea, amino acids, and DOC; Strom et al. 1997, Urban-Rich 1997). It follows from Eq. (1) that:

$$
A_{\mathrm{x}}=P_{\mathrm{x}}+R_{\mathrm{x}}+E_{\mathrm{x}}
$$

The dimensions of $I, A, F, P, R$, and $E$ are the same, i.e. time $^{-1}$ in the case of specific rates, or (mass $\times$ volume $^{-1}$ $\times$ time $^{-1}$ ) or (mass $\times$ surface $^{-1} \times$ time $^{-1}$ ) for volumetric or areal rates, respectively.

Eqs. (1) \& (2) apply to metazoans. In the case of protozoans, $F$ and $E$ are generally not separated. For microzooplankton (subscript ' $\mu z$ '; Fig. 2b), Eq. (1) becomes:

$$
I_{\mu \mathrm{z}}=A_{\mu \mathrm{z}}+E_{\mu \mathrm{z}}=\left(P_{\mathrm{\mu z}}+R_{\mathrm{\mu z}}\right)+E_{\mathrm{\mu z}}
$$

where $E_{\mathrm{\mu z}}$ includes $F_{\mathrm{\mu z}}$. Eq. (3) is consistent with Straile (1997).

In the case of osmotrophs, such as bacteria (subscript ' $b$ '), there is no egestion or excretion of non-metabolized organic matter (i.e. $F=0$ and $E=0$; hence $I_{\mathrm{b}}=A_{\mathrm{b}}$ ). In the specific case of viral lysis of bacteria $\left(L_{\mathrm{b}}\right)$ there is, as discussed below, a release of DOC into the surrounding medium. In the literature, the terms 'assimilation' $(A)$, 'uptake' $(U)$, and 'incorporation' are often used interchangeably for bacteria. Hence, Eqs. (1) \& (2) are rewritten as:

$$
I_{\mathrm{b}}=A_{\mathrm{b}}=\left(U_{\mathrm{b}}\right)=P_{\mathrm{b}}+R_{\mathrm{b}}+L_{\mathrm{b}}
$$

This partitioning is illustrated in Fig. 2c.

In Eqs. (1) \& (2), $I$ and $A$ are related to $P$ by growth efficiencies (e.g. Straile 1997). Net growth efficiency (NGE) and gross growth efficiency (GGE), i.e.:

$$
\begin{aligned}
& \mathrm{NGE}_{\mathrm{x}}=P_{\mathrm{x}} / A_{\mathrm{x}} \\
& \mathrm{GGE}_{\mathrm{x}}=P_{\mathrm{x}} / I_{\mathrm{x}}
\end{aligned}
$$

are related by the assimilation efficiency (AE) as shown in Eqs. (7) \& (8):

$$
\mathrm{AE}_{\mathrm{x}}=A_{\mathrm{x}} / I_{\mathrm{x}}
$$

hence:

$$
\mathrm{GGE}_{\mathrm{x}}=\mathrm{AE}_{\mathrm{x}} \times \mathrm{NGE}_{\mathrm{x}}
$$

Because $\mathrm{AE}_{\mathrm{x}}<1$, then $\mathrm{GGE}_{\mathrm{x}}<\mathrm{NGE}_{\mathrm{x}}$. NGE, GGE, and $\mathrm{AE}$ are dimensionless quantities. 


\section{Effects of DOC release from bacteria}

Viral lysis is responsible for a substantial fraction of bacterial mortality in aquatic environments. Because accurate estimates of virus-mediated mortality remain elusive (Suttle 2005, 2007), a generally accepted estimate is that viral lysis transforms into DOC 20 to $40 \%$ of daily bacteria production (Suttle 1994), which is of similar magnitude as mortality by microzooplankton grazing (Fuhrman \& Noble 1996). This process is not usually incorporated in biogeochemical or planktonic food-web models, although some food-web models account for viral lysis (e.g. Fuhrman 1992, 1999, Wilhelm \& Suttle 1999). Possible biogeochemical effects of viral lysis will be discussed below (section 'Model effects of DOC release from bacteria'). Viruses can also affect community composition, because infection is generally both host specific and density dependent (Fuhrman \& Schwalbach 2003). Hence, viruses appear to preferentially infect the most common hosts, leading to the 'kill the winner' hypothesis (Thingstad \& Lignell 1997). The 4 models used by Thingstad \& Lignell (1997) suggested that viruses can control the bacterial community structure (i.e. taxonomic composition) even when lysis is responsible for only a small fraction of the population mortality. This model prediction is supported by experimental evidence (e.g. Fuhrman \& Schwalbach 2003). It follows that the explicit inclusion of viruses in food-web and biogeochemical models would likely improve their descriptive and predictive capabilities. Because experimental data are lacking to realistically parameterize virus-related flows (Suttle 2007), we did not explicitly include viruses as a separate compartment in our model. However, as a first step, we considered the effects of viral lysis on modeled flows.

Eq. (4) includes bacterial mortality due to $L_{\mathrm{b}}$, which results in the release into the surrounding environment of organic matter that had been metabolized by bacteria. Thus, $L_{\mathrm{b}}$ is functionally equivalent to $E$ in metazoans (Eq. 2) and microzooplankton (Eq. 3). It is shown in Electronic Appendix 2 (section 'Effects of viral lysis of bacteria', available at http://www.int-res.com/ articles/suppl/m365p289_app.pdf) that the field methods for estimating $P_{\mathrm{b}}$ generally compute or observe changes in bacterial biomass that are net of both the loss of cellular material (i.e. $L_{\mathrm{b}}$ ) and the carbon catabolism (i.e. $R_{\mathrm{b}}$ ). Hence, net changes in biomass take into account the effect of $L_{\mathrm{b}}$ on the heterotrophic bacterial compartment as described in Eq. (4). It is also shown that the effect of $L_{\mathrm{b}}$ on bacterial growth efficiency (BGE) depends on how BGE was estimated. There are generally 2 ways to estimate BGE:

$$
\mathrm{BGE}_{1}=P_{\mathrm{b}} /\left(P_{\mathrm{b}}+R_{\mathrm{b}}\right)
$$

$$
\mathrm{BGE}_{2}=\left(P_{\mathrm{b}}+L_{\mathrm{b}}\right) / A_{\mathrm{b}}=\left(P_{\mathrm{b}}+L_{\mathrm{b}}\right) /\left(P_{\mathrm{b}}+R_{\mathrm{b}}+L_{\mathrm{b}}\right)
$$

Because the magnitude of $L_{\mathrm{b}}$ and mortality due to microzooplankton grazing may be similar (see below; in our model $L_{\mathrm{b}}=P_{\mathrm{b}}$ ), the effect of $L_{\mathrm{b}}$ on estimates of $\mathrm{BGE}_{2}$ could be large.

In the literature, $R_{\mathrm{b}}$ is generally computed from $P_{\mathrm{b}}$ and BGE (e.g. del Giorgio \& Cole 2000, Rivkin \& Legendre 2001):

$$
R_{\mathrm{b}}=\left(P_{\mathrm{b}} / \mathrm{BGE}\right)-P_{\mathrm{b}}
$$

Eq. (11) is correct when $\mathrm{BGE}=\mathrm{BGE}_{1}$ (Eq. 9). In that case, $R_{\mathrm{b}}$ requires knowledge of $P_{\mathrm{b}}$ and $\mathrm{BGE}_{1}$ from previous field or laboratory studies, but does not require an estimate of $L_{\mathrm{b}}$.

In addition to $L_{\mathrm{b}}$, other physiological mechanisms may contribute to the release of DOC from bacteria. Kawasaki \& Benner (2006) reported that during laboratory experiments with natural bacterial populations, the percentage of extracellular release of DOC [PER = DOC produced $\left./\left(\mathrm{DOC}_{\text {produced }}+\mathrm{POC}_{\text {produced }}\right)\right]$ ranged for bacteria from $\mathrm{PER}_{\mathrm{b}}=14$ to $31 \%$. If this process were confirmed by further laboratory and field studies, Eq. (10) could be modified to include $\mathrm{PER}_{\mathrm{b}}$ in the calculation of BGE:

$$
\mathrm{BGE}_{3}=\left(P_{\mathrm{b}}+L_{\mathrm{b}}+\mathrm{PER}_{\mathrm{b}}\right) /\left(P_{\mathrm{b}}+R_{\mathrm{b}}+L_{\mathrm{b}}+\mathrm{PER}_{\mathrm{b}}\right)
$$

The effect of $\mathrm{PER}_{\mathrm{b}}$ on estimates of BGE can be large. However, when BGE $=\mathrm{BGE}_{1}$ (Eq. 9), as in the case of $L_{\mathrm{b}}$, Eq. (11) can be used to compute $R_{\mathrm{b}}$ without including $\mathrm{PER}_{\mathrm{b}}$.

Eqs. (1) to (8), and Fig. 2 show that, despite the large differences among the bacterial, microzooplankton, and mesozooplankton compartments of the pelagic food web, these can be modeled using the same basic set of equations. We use these equations in the planktonic food-web model developed below.

\section{ASSESSING THE ROLES OF PLANKTONIC FOOD-WEB COMPARTMENTS}

\section{Uses and misuses of $I_{x}: P P, A_{x}: P P$, and $R_{x}: P P$}

In the remainder of this review, the fundamental food-web characteristics $I, A, P$, and $R$ will be compared with and scaled to $P P$. Heterotrophic community production (i.e. $P_{\mathrm{C} \text { i }}$ subscript ' ${ }^{C}$ ', for heterotrophic community) is the sum of $P_{\mathrm{x}}$ from the different heterotrophic compartments. Building on previous studies (e.g. Strayer 1988, Nagata 2000, Anderson \& Ducklow 2001), we expand on the concept that, during steady state (conditions discussed below), $P_{\mathrm{C}}$ can exceed $P P$, i.e. often $P_{\mathrm{C}}>P P$. This is because some of the organic carbon that is ingested or assimilated by one heterotrophic 
compartment (e.g. $I_{\mathrm{x} 1}$ or $A_{\mathrm{x} 1}$ ) can be passed to other compartments where it contributes to their $I_{\mathrm{x}}$ (e.g. to $I_{\mathrm{x} 2 \text {, }}$ $I_{\mathrm{x} 3}$, etc.) or $A_{\mathrm{x}}$ (e.g. to $A_{\mathrm{x} 2}, A_{\mathrm{x} 3}$, etc.). In other words, both $I_{\mathrm{x}}$ and $A_{\mathrm{x}}$ for individual heterotrophic compartments are not mutually exclusive, i.e. $I_{\mathrm{x} 1}, I_{\mathrm{x} 2}, I_{\mathrm{x} 3}, \ldots$ are not exclusive of each other, and $A_{\mathrm{x} 1}, A_{\mathrm{x} 2}, A_{\mathrm{x} 3}, \ldots$ are not exclusive of each other. It follows that $A_{\mathrm{C}}>P P$ (where $A_{\mathrm{C}}=A_{\mathrm{x} 1}+$ $\left.A_{\mathrm{x} 2}+A_{\mathrm{x} 3}+\ldots\right)$, and $I_{\mathrm{C}}>P P\left(\right.$ where $I_{\mathrm{C}}=I_{\mathrm{x} 1}+I_{\mathrm{x} 2}+I_{\mathrm{x} 3}+$ ...). Similarly, $P_{\mathrm{x} 1}, P_{\mathrm{x} 2}, P_{\mathrm{x} 3}, \ldots$ are not mutually exclusive, and as a consequence, $P_{\mathrm{C}}>1$ or $P_{\mathrm{C}} \leq 1$, depending on the values of the $\mathrm{NGE}_{\mathrm{x}}$. Consequently, $I, A$, and $P$ are not additive properties of an ecosystem. It follows that the ratios $I_{\mathrm{x}}: P P, A_{\mathrm{x}}: P P$, and $P_{\mathrm{x}}: P P$ for a specific food-web compartment have no diagnostic value, and provide neither ecologically relevant information on the partitioning of $P P$ among heterotrophic compartments (except when these are restricted to exclusively herbivorous consumers of phytoplankton) nor a basis for comparisons among different compartments within the same system (or the same compartments in different environments). Despite this limitation in their use, values of $I_{\mathrm{x}}: P P, A_{\mathrm{x}}: P P$, or $P_{\mathrm{x}}: P P$ for individual heterotrophic compartments are often reported in the literature, where they are incorrectly ascribed quantitative diagnostic value and lead to misinterpretation of ecological and food-web relationships. Hence, the use of $I_{\mathrm{x}}: P P$, $A_{\mathrm{x}}: P P$, or $P_{\mathrm{x}}: P P$ should be restricted to the specific case where ' $\mathrm{x}$ ' refers to exclusively herbivorous consumers of phytoplankton.

In contrast to $I_{\mathrm{x}}, A_{\mathrm{x}}$ and $P_{\mathrm{x},} R_{\mathrm{x}}$ by any individual heterotrophic compartment is exclusive and independent of all other heterotrophic compartments, i.e. the organic carbon that is respired by one compartment is transformed to $\mathrm{CO}_{2}$ and is therefore not available to other heterotrophic compartments. Hence, at steady state, $R_{\mathrm{C}}$ cannot exceed $P P$, and, consequently, respiration is an additive property of the ecosystem. Indeed, $R$ is the only such property. Because of the additive nature of $R$, the fraction of $P P$ respired by a given heterotrophic compartment (i.e. $R_{\mathrm{x}}: P P$ ), or the fraction of total heterotrophic respiration accounted for by that compartment (i.e. $R_{\mathrm{x}}: R_{\mathrm{C}}$ ), can be used as a metric for assessing trophic conditions or comparing food-web compartments.

We have shown that ecosystem properties other than $R$ (e.g. $I, A$, and $P$ ) are not additive. Yet, $P_{\mathrm{x}}: P P$ values are frequently reported in the literature, which may suggest that $P_{\mathrm{x}}: P P$ contains useful and diagnostic food-web information, e.g. for comparing either a given food-web compartment under different environmental conditions, or different food-web compartments within a given system. It is shown in Electronic Appendix 2 (section 'Use of $P_{\mathrm{x}}: P P$ instead of $R_{\mathrm{x}}: P P^{\prime}$ ) that this is not the case, and that using $P_{\mathrm{x}}: P P$ instead of $R_{\mathrm{x}}: P P$ biases the characterization of food-web relationships. Even if properties other than $R$ are not appropriate for comparing foodweb compartments, we show below that, for the whole heterotrophic community, $A_{C}: P P$ may provide an indication of the fraction of carbon recycled within a whole food web (section 'Model results'; discussion of Table 6).

We explained above that $A_{\mathrm{C}}>P P$ under steady-state conditions. We define a steady-state food web as one where the biomasses of the food-web compartments are constant. In the ocean, an additional steady-state condition is when there is no net import $(M)$ or export $(X)$ of organic carbon from and to the euphotic zone. These 2 steady-state conditions are examined in Electronic Appendix 2 (section 'Conditions for $A_{\mathrm{x}}>P P$ in the ocean'). The conclusions for non-steady-state situations, where $M>X$ and $X>M$, are summarized in Table 2, which shows that the only case where $A_{\mathrm{C}}<P P$ is when both $X>M$ and $(X-M)>\left(P_{\mathrm{C}}+E_{\mathrm{C}}\right)$. Hence, even under non-steady-state conditions, generally $A_{\mathrm{C}}>P P$.

\section{Effects of dissolved $P P$ on estimates of $R_{x}: P P$}

Values of $R_{\mathrm{x}}: P P$ (or $R_{\mathrm{C}}: P P$ ) reported in the literature are often not comparable because of the use of different variables in the denominator. For example, $R_{\mathrm{x}}$ is generally divided by $P P_{\mathrm{P}}$. However, the dissolved component of $P P$ (i.e. $P P_{\mathrm{D}}$ ) can account for a significant fraction of total $P P\left(P P_{\mathrm{T}}=P P_{\mathrm{D}}+P P_{\mathrm{P}}\right)$, with a global median of $P P_{\mathrm{D}}: P P_{\mathrm{T}}$ (i.e. PER) of 15 to $20 \%$. Given that osmotrophy by bacteria is a dominant pathway of organic carbon remineralization in the sea, the denominator in any computation of the fraction of $P P$ respired

Table 2. Influence of the relative magnitudes of $M$ and $X$ on the relative magnitudes of $A_{C}$ and $P P$. In cases where $X>M$, it is necessary to consider the balance between $X-M$ and $P_{\mathrm{C}}+E_{\mathrm{C}}$ to resolve the relation between $A_{\mathrm{C}}$ and $P P$. Predictions are explained in Electronic Appendix 2 (section 'Conditions for $A_{\mathrm{C}}>P P$ in the ocean') (available at www.int-res.com/articles/suppl/m365p289_app.pdf). DOC: dissolved organic carbon; POC: particulate organic carbon

\begin{tabular}{|llcc|}
\hline$M$ and $X$ & Ocean examples & Condition & $A_{\mathrm{C}}$ and $P P$ \\
\hline$M=X$ & Large scale and long term & None & $A_{\mathrm{C}}>P P$ \\
$M>X$ & Near-shore waters (i.e. import & None & $A_{\mathrm{C}}>P P$ \\
& $\begin{array}{l}\text { of continental DOC) and areas of } \\
\text { the ocean where } R_{\mathrm{T}}>P P \text { (i.e. net }\end{array}$ & & \\
& heterotrophic regions) & & \\
$X>M$ & $\begin{array}{l}\text { Areas of high } P P, \text { where } P P>R_{\mathrm{T}} \\
\text { and from which POC and/or DOC }\end{array}$ & $(X-M)<\left(P_{\mathrm{C}}+E_{\mathrm{C}}\right)$ & $A_{\mathrm{C}}>P P$ \\
& $\begin{array}{l}\text { are exported downwards and/or } \\
\text { advected laterally }\end{array}$ & & \\
& & & \\
\hline
\end{tabular}


must include $P P_{\mathrm{D}}$ as well as $P P_{\mathrm{P}}$ (i.e. $R_{\mathrm{x}}: P P_{\mathrm{T}}$ ) if this ratio is to be used as valid a metric for assessing trophic conditions or comparing food-web compartments (Electronic Appendix 2, section 'Effects of dissolved $P P$ on estimates of $R_{\mathrm{x}}: P P^{\prime}$ ). Another approach to estimate $R_{\mathrm{x}}: P P$ was described by Calbet \& Landry (2004) for microzooplankton. They computed $R_{\mu z}: P P_{\mathrm{P}}$ by multiplying $I_{\mathrm{\mu z}}: P P_{\mathrm{P}}$ (determined from dilution experiments) by a literature-derived value of $R_{\mu \mathrm{z}}: I_{\mu \mathrm{z}}$. The resulting value of $R_{\mu \mathrm{z}}: P P_{\mathrm{P}}$ depends, however, on the specific $R_{\mu z}: I_{\mu z}$ value that is used (see Electronic Appendix 2).

In Table 3, we report estimates of carbon assimilation and respiration by bacteria $\left(A_{\mathrm{b}}\right.$ and $R_{\mathrm{b}}$, respectively) and microzooplankton ( $A_{\mu z}$ and $R_{\mu z}$, respectively), and the corresponding sums of assimilation $\left(A_{\mathrm{b}}\right.$ $\left.+A_{\mu \mathrm{z}}\right)$ and respiration $\left(R_{\mathrm{b}}+R_{\mu \mathrm{z}}\right)$, in 3 zones of the world ocean. Each estimate is expressed as a fraction of both $P P_{\mathrm{P}}$ and $P P_{\mathrm{T}}$ (additional details are given in Electronic Appendix 2). The results in Table 3 illustrate 2 important points about the relationships among respiration, assimilation, and photosynthesis. First, the table shows the effect of using $P P_{\mathrm{P}}$ instead of $P P_{\mathrm{T}}$ as the denominator in respiration ratios. Ratios computed with $P P_{\mathrm{P}}$ $\left(\sum R: P P_{\mathrm{P}}\right)$ can be $\geq 1$, whereas those computed with $P P_{\mathrm{T}}$ are $<1$. Second, the table demonstrates that the sum of $A_{\mathrm{b}}$ and $A_{\mu z}$ exceeds $P P_{\mathrm{T}}$ (i.e. $\sum A: P P_{\mathrm{T}}>1.0$ ), illustrating the non-additive nature of $A$ (and consequently $I$, because $I>A$ ). In contrast $\sum R: P P_{\mathrm{T}} \leq 1.0$, illustrating the additive nature of $R$. It is shown in Electronic Appendix 2 that to compare ecosystem or food-web responses using ratios of respiration to an ecosystem property, the denominator must be the same. This is frequently not done, and leads to confusion in the literature. We propose that to compare marine ecosystems, the numerator of ratios should be $R_{\mathrm{x}}$ and the denominator should be $R_{\mathrm{C}}$ or $P P_{\mathrm{T}}$.

Although the organic carbon that is taken up and respired by bacteria may have been channeled through many other food-web components before being assimilated by bacteria during long-term steady state, it was originally produced by phytoplankton $\left(P P_{\mathrm{T}}\right)$. In Table 3 , where we assumed that $P P_{\mathrm{D}}: P P_{\mathrm{T}}=$ $0.2, R_{\mathrm{b}}: P P_{\mathrm{T}}$ thus $\sim 0.50$ to 0.75 . This means that in addition to the DOC that was released directly by phytoplankton $\left(P P_{\mathrm{D}}\right)$, bacteria also require organic carbon that originated from $P P_{\mathrm{P}}$ and was channeled to them via the food web. If we assume that bacteria assimilate and respire all of the $P P_{\mathrm{D}}$, we can compute the fraction of the $P P_{\mathrm{P}}$-derived carbon required for bacterial respiration as:

$$
\left.\left(R_{\mathrm{b}}: P P_{\mathrm{T}}\right)-\left(P P_{\mathrm{D}}: P P_{\mathrm{T}}\right)\right] /\left(P P_{\mathrm{P}}: P P_{\mathrm{T}}\right)
$$

Assuming $P P_{\mathrm{D}}: P P_{\mathrm{T}}=0.2$, and with a range of $R_{\mathrm{b}}: P P_{\mathrm{T}}$ $\approx 0.50$ to 0.75 (Table 3 ), Eq. (13) shows that bacteria will assimilate and respire $\sim 40$ to $70 \%$ of the organic carbon originating from $P P_{\mathrm{p}}$. These values underestimate bacterial carbon assimilation and respiration originating from $P P_{\mathrm{P}}$ because a fraction of the carbon from $P P_{\mathrm{D}}$ is transferred (via bacterivorous microzooplankton) to, and respired by, the food web and is thus not available for bacterial respiration. Below, our model examines the channeling of organic carbon from $P P_{\mathrm{P}}$ to bacteria (and microzooplankton) by food-web processes, and its further channeling to metazoans.

Table 3. Assimilation and respiration by BACT ( $A_{\mathrm{b}}$ and $R_{\mathrm{b}}$, respectively), $\mu \mathrm{ZOO}\left(A_{\mu \mathrm{z}}\right.$ and $R_{\mu \mathrm{z}}$, respectively), and the sums for BACT and $\mu$ ZOO (i.e. $\sum A=A_{\mathrm{b}}+A_{\mu \mathrm{z}}$ and $\sum R=R_{\mathrm{b}}+R_{\mathrm{uz}}$ ), in 3 zones of the world ocean. The values of $A$ and $R$ are separately expressed as a fraction of both particulate primary production $\left(P P_{\mathrm{P}}\right)$ and total primary production $\left(P P_{\mathrm{T}}\right)$. Values were computed assuming that dissolved primary production $\left(P P_{\mathrm{D}}\right)$ was equivalent to $20 \%$ of $P P_{\mathrm{T}}$. $A_{\mathrm{b}}$ (i.e. bacterial carbon demand) and $R_{\mathrm{b}}$ were calculated from a global database on BACT properties (Rivkin \& Legendre 2002). $R_{\mathrm{b}}$ was computed from $P_{\mathrm{b}}$, BGE $\mathrm{E}_{1}$, and temperature (Rivkin \& Legendre 2001). $P P_{\mathrm{P}}$ was derived from SeaWiFs images for 1998 by David Antoine (pers. comm.) and from CZCS climatology. Average $A_{\mathrm{b}}$ (where $A_{\mathrm{b}}=R_{\mathrm{b}}+P_{\mathrm{b}}$ ), $R_{\mathrm{b}}$, and $R_{\mathrm{b}}: P P_{\mathrm{P}}$ were computed for 2-degree latitude zonal bands (integrated down to $100 \mathrm{~m})$, and the zones were aggregated into 3 regions: polar $\left(>56^{\circ} \mathrm{S}\right.$ and $\left.>56^{\circ} \mathrm{N}\right)$, temperate $\left(22\right.$ to $55^{\circ} \mathrm{S}, 22$ to $\left.55^{\circ} \mathrm{N}\right)$, and tropical $\left(22^{\circ} \mathrm{S}\right.$ to $\left.22^{\circ} \mathrm{N}\right)$. Each value was first arctangent transformed in order to reduce the effect of large ratios on computed averages and normalized. The regional arctangent averages were converted back to ratios of $A_{\mathrm{b}}: P P_{\mathrm{P}}$ or $R_{\mathrm{b}}: P P_{\mathrm{P}}$ using the inverse function (i.e. tangent). Values of $A_{\mu z}: P P_{\mathrm{P}}$ are from Calbet \& Landry (2004; last column of their Table 1). In their paper, they estimated $R_{\mu \mathrm{z}}: P P_{\mathrm{P}}$ by multiplying $A_{\mu \mathrm{z}}: P P_{\mathrm{P}}$ by a constant $R_{\mu \mathrm{z}}: I_{\mathrm{\mu z}}=0.5$, to which they added $5 \%$ of $P P_{\mathrm{P}}$ to account for the feeding of bacterivorous protozoans on $P_{\mathrm{b}}$. In the present table, we calculated temperature-dependent $R_{\mu \mathrm{z}}: P P_{\mathrm{P}}$ from the $A_{\mu z}: P P_{\mathrm{P}}$ values of Calbet \& Landry (2004) and our Eqs. (A4) to (A9) in the Electronic Appendix 1 (available at www.int-res.com/articles/suppl/m365p289_ app.pdf), to which we added $5 \%$ of $P P_{\mathrm{p}}$ as in Calbet \& Landry (2004). The average temperatures extracted from our BACT data base were $\sim 2,15$, and $25^{\circ} \mathrm{C}$ for the polar, temperate, and tropical zones, respectively

\begin{tabular}{|c|c|c|c|c|c|c|c|c|c|c|c|c|}
\hline \multirow{2}{*}{$\begin{array}{l}\begin{array}{l}\text { Denominator: } \\
\text { Food-web process: }\end{array} \\
\text { Numerator }\end{array}$} & \multicolumn{6}{|c|}{$P P_{\mathrm{P}}$} & \multicolumn{3}{|c|}{ Assimilation } & $P P_{\mathrm{T}}$ & \multicolumn{2}{|c|}{ espiration } \\
\hline & $A_{\mathrm{b}}$ & $A_{\mu z}$ & $\sum A$ & $R_{\mathrm{b}}$ & $R_{\mu z}$ & $\sum R$ & $A_{\mathrm{b}}$ & $A_{\mu z}$ & $\sum A$ & $R_{\mathrm{b}}$ & $R_{\mu \mathrm{z}}$ & $\sum R$ \\
\hline Polar & 0.81 & 0.59 & 1.40 & 0.70 & 0.14 & 0.84 & 0.65 & 0.47 & 1.12 & 0.56 & 0.11 & 0.67 \\
\hline Temperate & 0.88 & 0.61 & 1.49 & 0.65 & 0.18 & 0.83 & 0.70 & 0.49 & 1.19 & 0.52 & 0.15 & 0.67 \\
\hline Tropical & 1.03 & 0.75 & 1.78 & 0.94 & 0.26 & 1.20 & 0.82 & 0.60 & 1.42 & 0.75 & 0.21 & 0.96 \\
\hline
\end{tabular}




\section{STEADY-STATE PLANKTONIC FOOD-WEB MODEL}

\section{Model structure}

We initially explore the roles of heterotrophic microbes in planktonic food webs using the food-web model introduced in Fig. 1a. Our model examines the fate of $P P_{\mathrm{T}}$ that is respired within the euphotic zone, i.e. $P P_{\mathrm{T}}$ that is not exported either directly as phytodetritus, or indirectly as marine snow and refractory DOC, or via vertically migrating organisms.

The 'currency' of our model is carbon. In the figure, boxes represent food-web compartments, and arrows are flows of carbon into and out of the compartments (capital italic letters; symbols of heterotrophic flows are summarized in Table 1). The model includes 7 compartments, which are all simplifications of complex in situ situations: (1) particulate organic carbon (POC) is produced by phytoplankton (PHYTO; i.e. $\left.P P_{\mathrm{P}}\right) ;(2)$ DOC is from phytoplankton (i.e. $P P_{\mathrm{D}}$ ) and excreted by eukaryotic heterotrophs; (3) heterotrophic picoplankton (called simply 'bacteria' and abbreviated BACT) use both DOC and detrital POC (DETR); (4) microzooplankton $(\mu \mathrm{ZOO})$, i.e. heterotrophic flagellates, dinoflagellates, and ciliates, consume both phytoplankton and bacteria; (5) mesozooplankton (MZOO), e.g. copepods, consume phytoplankton, $\mu \mathrm{ZOO}$, and DET (some studies have suggested that small-sized copepods may rely more on microzooplankton for food than do larger primarily herbivorous copepods, e.g. Castellani et al. 2005); (6) large heterotrophs (LARGE), e.g. large zooplankton and fish, consume MZOO or food that is derived from MZOO; and (7) DETR comes from metazoans, mostly mesozooplankton. In the model, primary production is the net output of autotrophic respiration, and all the organic carbon that is not exported from the euphotic zone is respired by heterotrophs, i.e. BACT, $\mu \mathrm{ZOO}, \mathrm{MZOO}$, and LARGE. For simplicity, we assume that the food web is in steady state, i.e. all of the production by one compartment is consumed by other compartments, and hence there is no net change in the biomass of any of the compartments. In the model, the fraction of $P P_{\mathrm{P}}$ channeled to $\mu \mathrm{ZOO}$ and $\mathrm{MZOO}$, respectively, is independent from the size structure of PHYTO, and depends solely on the relative grazing activities of the 2 groups of organisms. Since the distributions and food-web parameters of mixotrophic organisms, which can both photosynthesize and utilize reduced organic carbon, are poorly characterized, we did not created a separate compartment for these organisms in our model; however, when mixotrophic processes are properly parameterized, the effect of these organisms on food-web flows could be included in the model as explained below. All flows in the model are normalized on an areal basis.
Lateral and vertical fluxes of organic carbon in the water column, viral lysis of bacteria, and formation of phytodetritus are not shown in Fig. 1a, for simplicity. These processes are discussed below with respect to food-web carbon flows. Other processes, such as photochemically (i.e. UV) driven degradation of refractory colored organic matter to labile DOC, photo-oxidation of DOC to $\mathrm{CO}_{2}$ (e.g. Bushaw et al. 1996, Moran \& Zepp 1997, Moran \& Miller 2007), and abiotic formation of particles from DOC (e.g. Verdugo et al. 2004, Jensen \& Søndergaard 1982) are not discussed here because they are not driven by the food web, although they may influence food-web processes. Transparent exopolymeric particles (TEP) can function as sorption sites for dissolved organic and inorganic matter, and attachment sites for bacteria (Azam \& Malfatti 2007), and can be a food source for a number of particle feeders (e.g. protozoans, copepods, and tunicates). Most of TEP that is formed within the euphotic zone will aggregate, with other particles, into marine snow and is exported out of the euphotic zone (e.g. Engel et al. 2004, and references in Mari \& Dam 2004). Because our model considers only the carbon that is processed in the euphotic zone, the formation of TEP is not included. Finally, Fig.1a does not include, for simplicity, alteration of the molecular structure of DOM by microbial processes, which makes DOM resistant to further degradation and thereby preserves organic carbon in the ocean as refractory DOC (e.g. in the laboratory study of Ogawa et al. [2001] marine bacteria produced refractory DOC equal to ca. $5 \%$ of the initial labile DOC added)

The model shown in Fig. 1a is not intended to reproduce field observations, instead it is meant to explore the effects of food-web structure on selected ecosystem processes. Here, we quantitatively develop our steadystate model by progressively increasing its complexity, as shown in Fig. 3. Our model is temperature dependent and incorporates temperature dependence of the growth efficiencies of BACT, $\mu \mathrm{ZOO}$ and MZOO. Growth efficiencies are influenced by both environmental and biological factors (e.g. Straile 1997, for $\mathrm{ZOOO}$ and MZOO; del Giorgio \& Cole 2000, for BACT; Ikeda et al. 2001, for MZOO), which include concentration and quality of organic substrates, inorganic nutrients, and temperature (BACT), food concentration and temperature ( $\mu \mathrm{ZOO}$ and $\mathrm{MZOO})$, and general physiological condition (all food-web compartments; Anderson 2005, Mitra \& Flynn 2005); in our modeling exercise, we consider only the effect of temperature, as a first step in the implementation of the microbial-hub approach. Finally, since mesopelagic food-web processes are poorly known, our model considers the fate of $P P_{\mathrm{T}}$ to be respired within the euphotic zone only (i.e. $P P_{\mathrm{T}}$ that is not exported), and by definition, $R_{\mathrm{C}}=P P_{\mathrm{T}}$. 
Step 1

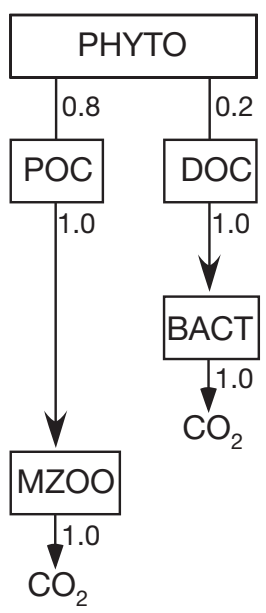

Step 5

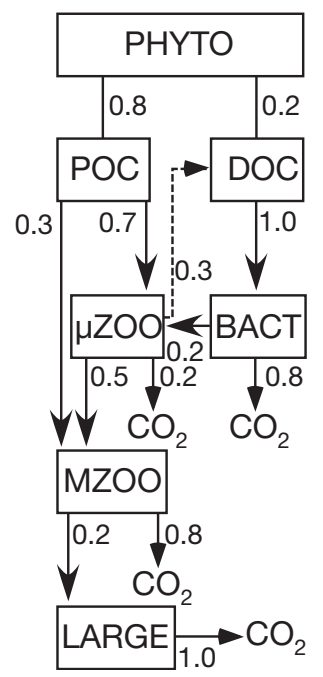

Step 2

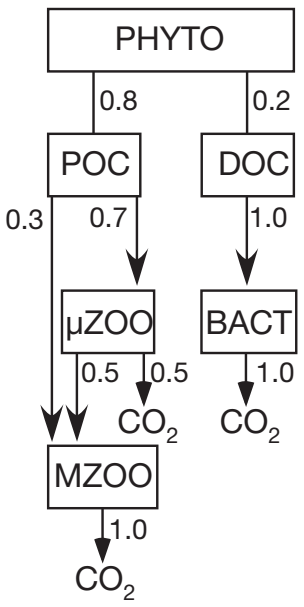

Step 3

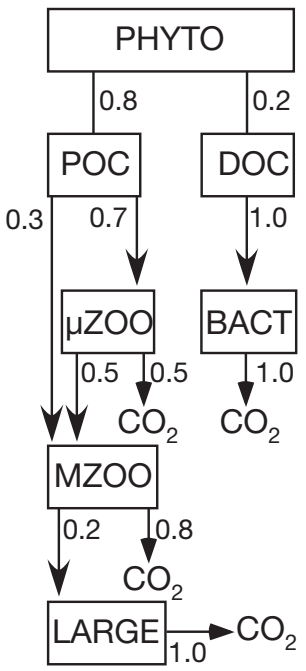

Step 4

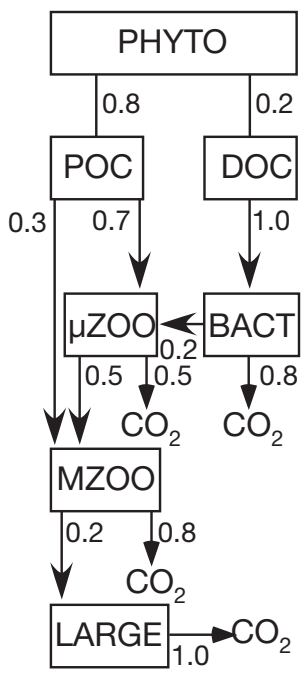

Step 7: final

Step 6
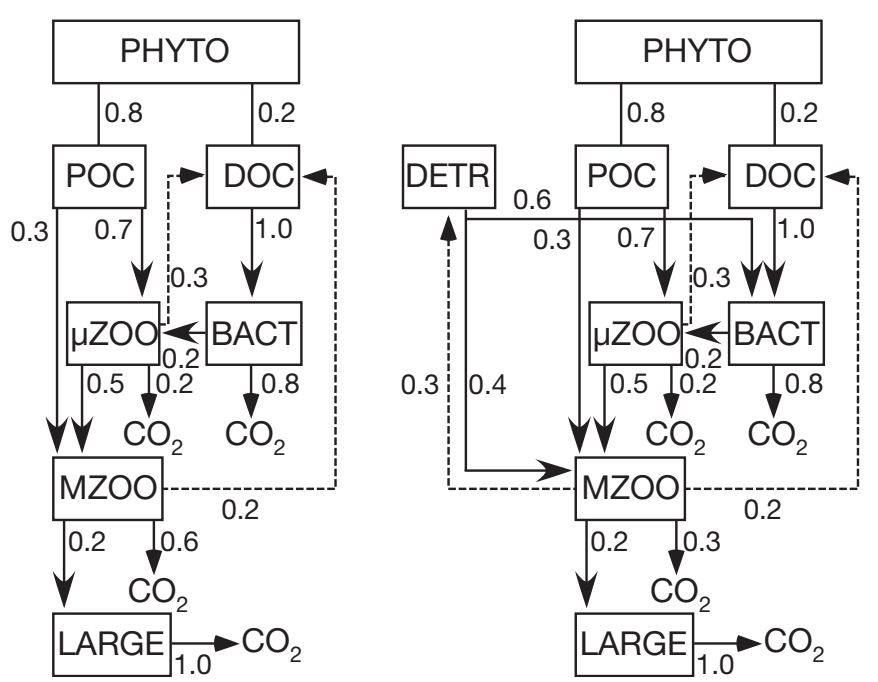

Fig. 3. The 7 steps in the development of the steady-state food-web model introduced in Fig. 1a. The 'currency' of the model is carbon. Primary production is the net output of respiration, and all the organic carbon that is not exported from the euphotic zone is respired by heterotrophs. In the model, the biomass of each compartment is constant (steady state). The different steps are characterized in Table 4 (the values of flows for Step 7 of the model here correspond to the multivorous food web; see 'Steady-state planktonic food-web model-Model structure'), and the modeled flows are summarized in Tables 5 \& 6 . Solid arrows: forward flows; dashed arrows: backward flows

In steady-state models, the sum of flows of carbon out of a compartment (output flows, e.g. $R_{\mathrm{x},} E_{\mathrm{x},}$ and $P_{\mathrm{x}}$ ) is equal to the sum of flows into that same compartment (input flows, e.g. $I_{\mathrm{x}}, A_{\mathrm{x}}$ ). The organic carbon that enters a compartment is partitioned among different food-web processes. The parameters of our model are the output flows (arrows) illustrated in Fig. 3, each computed as a fraction of the total input flows into that compartment (e.g. parameter $R_{\mu \mathrm{zz}}$ is expressed as a fraction of the sum of POC and BACT grazed by $\mu \mathrm{ZOO})$. Hence, the sum of the output-flow parameters from any compartment is equal to 1 . Details on model parameters and on our calculation of steady-state solutions are given in Electronic Appendix 1 (available at www.int-res.com/articles/suppl/m365p289_app.pdf).

Fig. 3 illustrates the intermediate models leading to the development of the most complex food-web model, i.e. Step 7. Each model step represents an increasing level of complexity, as defined by an increase in the number of between-compartment flows (steps are summarized in Table 4). At Step 1, the model consists of 2 linear food chains: (1) from $P P_{\mathrm{P}}$ to $\mathrm{MZOO}\left(P P_{\mathrm{Pmz}}\right)$, 
i.e. the zooplankton food chain, and (2) from $P P_{\mathrm{D}}$ to $\mathrm{BACT}$, i.e. the bacterial food chain. At Step $2, P P_{\mathrm{P}}$ is consumed by both $\mu \mathrm{ZOO}\left(P P_{\mathrm{P \mu z}}\right)$ and MZOO (the partitioning of $P P_{\mathrm{P}}$ between $P P_{\mathrm{P \mu z}}$ and $P P_{\mathrm{Pmz}}$ is determined by the ingestion characteristics of $\mu \mathrm{ZOO}$ and MZOO, respectively), and $\mu \mathrm{ZOO}$ are consumed by MZOO. At Step 3, the zooplankton food chain is lengthened to include LARGE. At Step 4, BACT are consumed by $\mu \mathrm{ZOO}$, and the 2 parallel food chains are thus linked to form a food web. At Steps 5 and $6, \mu \mathrm{ZOO}$ and MZOO, respectively, excrete DOC, which is used by bacteria. At Step 7, there is egestion (i.e. fecal material and soma, e.g. copepod exuviates, appendicularian houses) by MZOO. There are 2 pathways leading from DETR to BACT: (1) release of DOC from fecal pellets (e.g. up to $50 \%$ solubilization; Urban-Rich 1999) and (2) use of particulate DETR by MZOO and BACT; in the latter, attached bacteria hydrolyze detrital POC to DOC, which is then assimilated by both free and attached bacteria (Azam \& Smith 1991, Smith et al. 1992, Unanue et al. 1998). There may be competition for DETR between BACT and MZOO. Table 4 shows that the number of flows increases from 4 at Step 1 to 15 at Step 7.

We computed the flows for Step 7 of the model for 5 different planktonic food webs, i.e. the microbial, multivorous, and herbivorous food webs, and 2 additional cases that represent extreme food webs. The structure

Table 4. Progression in the development of the steady-state food-web models illustrated in Fig. 3. Parameterization of the model is detailed in Electronic Appendix 1 (available at www.int-res.com/articles/suppl/m365p289_app.pdf). Last column: number of flows at each step of the model

\begin{tabular}{|c|c|c|}
\hline Step & Description of flows & No. of flows \\
\hline 1 & $\begin{array}{l}\text { 'Skeleton' model; } 4 \text { flows: } \mathrm{PHYTO} / \mathrm{POC} \text { to } \mathrm{MZOO} \text {, } \\
\mathrm{PHYTO} / \mathrm{DOC} \text { to BACT, and respiration by } \mathrm{MZOO} \\
\text { and } \mathrm{BACT} \text { of the entire organic } \mathrm{C} \text { they ingest } \\
\left(100 \% \text { to } \mathrm{CO}_{2}\right)\end{array}$ & 4 \\
\hline 2 & $\begin{array}{l}\text { Step } 1+3 \text { flows: PHYTO/POC to } \mu \mathrm{ZOO}, \mu \mathrm{ZOO} \text { to } \\
\text { MZOO, and respiration by } \mu \mathrm{ZOO} \text { of part of the } \\
\text { organic } \mathrm{C} \text { they ingest }\end{array}$ & 7 \\
\hline 3 & $\begin{array}{l}\text { Step } 2+2 \text { flows: MZOO to LARGE and respiration } \\
\text { by LARGE of the entire organic carbon they ingest } \\
\left(100 \% \text { to } \mathrm{CO}_{2}\right)\end{array}$ & 9 \\
\hline 4 & Step $3+1$ flow: BACT to $\mu \mathrm{ZOO}$ & 10 \\
\hline 5 & Step $4+1$ flow: $\mu \mathrm{ZOO}$ to DOC (to BACT) & 11 \\
\hline 6 & Step $5+1$ flow: MZOO to DOC (to BACT) & 12 \\
\hline 7 (final) & $\begin{array}{l}\text { Step } 6+3 \text { flows: MZOO to DETR, DETR to MZOO, } \\
\text { and DETR to BACT }\end{array}$ & 15 \\
\hline \multicolumn{3}{|c|}{$\begin{array}{l}\text { an our model, (i) } P P_{\mathrm{P}} \text { is not modeled as a distinct flow, but is partitioned ini- } \\
\text { tially between } P P_{\mathrm{P} \mu \mathrm{z}} \text { and } P P_{\mathrm{Pmz}} \text { and (ii) the DOC compartment is not mod- } \\
\text { eled explicitly, because } P P_{\mathrm{D}}, E_{\mu z} \text { and } E_{\mathrm{mz}} \text { are channeled directly to BACT. } \\
\text { Hence, PHYTO to POC and DOC to BACT are not counted as parameter } \\
\text { flows in this table }\end{array}$} \\
\hline
\end{tabular}

of the microbial, multivorous, and herbivorous food webs was defined by Legendre \& Rassoulzadegan (1995). In order to illustrate our model, we use here the field characteristics of the 3 food webs that were empirically determined by Mousseau et al. (2001), based on observations on the Scotian Shelf, off Eastern Canada, and in the adjacent Gulf of St. Lawrence. The fraction of large-sized ( $>5 \mu \mathrm{m}, P P_{\mathrm{PL}}$ ) to total $P P_{\mathrm{P}}$ (i.e. $P P_{\mathrm{PL}}: P P_{\mathrm{P}}$ ) for the 3 food webs was $<0.2,0.2$ to 0.5 , and $>0.5$, respectively (Mousseau et al. 2001). We assumed that $P P_{\mathrm{Pmz}}: P P_{\mathrm{p}}=P P_{\mathrm{PL}}: P P_{\mathrm{P} i}$ even if in oceans, mesozooplankton seldom consume all $P P_{\mathrm{PL}}$, this assumption provides a first-order approximation for $P P_{\mathrm{Pmz}}: P P_{\mathrm{p}}$. Using the reported $P P_{\mathrm{PL}}: P P_{\mathrm{P}}$ values, we estimated the fraction of non-exported $P P_{\mathrm{P}}$ consumed by MZOO $\left(P P_{\mathrm{Pmz}}: P P_{\mathrm{P}}\right)$ in the microbial, multivorous, and herbivorous food webs to be $0.10,0.35$ and 0.75 , respectively (these are the mid-range values of the 3 size classes reported in Mousseau et al. 2001). We also included 2 additional food webs that represent extreme cases, where all $P P_{\mathrm{P}}$ would be grazed by either $\mu \mathrm{ZOO}$ $\left(P P_{\mathrm{Pmz}}: P P_{\mathrm{p}}=0 ;\right.$ called here extreme microbial $)$ or MZOO $\left(P P_{\mathrm{Pmz}}: P P_{\mathrm{p}}=1.0\right.$; called here extreme herbivorous). The latter, 2 extreme food webs (which are not normally observed in nature), are included in the present analysis to contrast the results. The $P P_{\mathrm{P}}$ consumed by $\mu \mathrm{ZOO}$ is $\left(1-P P_{\mathrm{Pmz}}: P P_{\mathrm{P}}\right)$. In our model, the only difference among the 5 food webs is the fraction of $P P_{\mathrm{P}}$ consumed directly by $\mu \mathrm{ZOO}$ and MZOO, respectively. Additional details are given in Electronic Appendix 1.

The presentation of planktonic food webs in the previous paragraph does not fully capture the presently known richness of trophic relationships among plankton groups. However, our model can accommodate, without modifying it, other situations than those originally described by Legendre \& Rassoulzadegan (1995) and characterized by Mousseau et al. (2001). This is because in our model, the fraction of $P P_{\mathrm{P}}$ channeled to $\mu \mathrm{ZOO}$ and $\mathrm{MZOO}$, respectively, solely depends on the relative grazing activities of the 2 groups of organisms and is thus independent of the size structure of PHYTO. Among the situations not considered above is the fact that protozoans often consume most $P P_{\mathrm{P}}$, including phytoplankton cells as large as (or larger than) themselves (e.g. reviews of Sherr \& Sherr 1994, 2008b); this situation is captured in our model by assigning a low value to $P P_{\mathrm{Pmz}}: P P_{\mathrm{P}}$, which corresponds to the 
microbial or extreme microbial food webs in the present modeling exercise. Conversely, microphagous macrozooplankton (also known as 'mucous-web plankton', which include salps, doliolids, appendicularians, and pteropods) sometimes consume most $P P_{\mathrm{P}}$ (e.g. review of Fortier et al. 1994); this situation is captured in our model by assigning a high value to $P P_{\mathrm{Pmz}}: P P_{\mathrm{P}}$, which corresponds to the herbivorous or extreme herbivorous food webs in the present modeling exercise. Also, the grazing of picoplankton-containing aggregates by mesozooplankton or microphagous macrozooplankton, which at times can be significant (e.g. Richardson \& Jackson 2007), is incorporated in the model by increasing $P P_{\mathrm{Pmz}}: P P_{\mathrm{p}}$. Similarly, the grazing activity of mixotrophic protozoans (e.g. Stoecker et al. 1987, 1989, Arenovski et al. 1995, Jones 2000, Troost et al. 2005) is included in the model by changing $P P_{\mathrm{Pmz}}: P P_{\mathrm{P}}$, so as to reflect the contributions of mixotrophs to both $P P_{\mathrm{Pmz}}$ and $P P_{\mathrm{P}}$.

Table 5. Modeled input $(I, A)$ and output $(F, P, R, E)$ flows corresponding to Step 7 of the steady-state food-web model illustrated in Fig. 3, and described in Table 4 and the Electronic Appendix 1 (available at www.int-res.com/journals/ suppl/m365p289_app.pdf). The flows are those calculated for the multivorous food web, at $15^{\circ} \mathrm{C}$. Each flow is expressed as a fraction of $P P_{\mathrm{T}} . \varnothing$ indicates that the flow does not exist for the given food-web compartment

\begin{tabular}{|lcccccc|}
\hline $\begin{array}{l}\text { Food-web } \\
\text { compartment }\end{array}$ & $I$ & $A$ & $F$ & $P$ & $R$ & $E$ \\
\hline BACT & 0.63 & 0.63 & $\varnothing$ & 0.14 & 0.49 & $\varnothing$ \\
$\mu Z O O$ & 0.66 & 0.66 & $\varnothing$ & 0.30 & 0.15 & 0.22 \\
MZOO & 0.66 & 0.46 & 0.20 & 0.16 & 0.20 & 0.10 \\
LARGE & 0.16 & 0.16 & $\varnothing$ & $\varnothing$ & 0.16 & $\varnothing$ \\
Total & 2.11 & 1.91 & 0.20 & 0.60 & 1.00 & 0.32 \\
& & & & & & \\
\hline
\end{tabular}

\section{Model results}

Table 5 reports the modeled input $(I, A)$ and output $(F, P, R, E)$ flows for the 4 heterotrophic food-web compartments at Step 7. Because the only additive property of the ecosystem is $R$, the other flows reported in Table 5 include contributions for organic carbon that has been recycled within the food web. Although we chose to develop the solution corresponding to the multivorous food web to illustrate general food-web properties, the conclusions would apply to the other food webs. Values comparable to ours were reported by Nagata (2000) for oligotrophic oceanic conditions (his model was with viral lysis): 0.42, 0.90, and 0.33, for $A_{\mathrm{b}}, A_{\mu \mathrm{z}}$ and $A_{\mathrm{mz}}$ respectively; our corresponding values for the microbial food web are quite similar, i.e. 0.69, 0.81, and 0.35 (viral lysis modeled with Eqs. (A19), (A22), \& (A23) in Electronic Appendix 1). Our modeled $I_{\mathrm{C}}: P P_{\mathrm{T}}, A_{\mathrm{C}}: P P_{\mathrm{T}}$, and $P_{\mathrm{C}}: P P_{\mathrm{T}}$ are 195,177 , and $53 \%$, respectively $\left(R_{\mathrm{C}}\right.$ consumes $100 \%$ of $P P_{\mathrm{T}}$, because the model is in steady state). The fact that only $R_{\mathrm{C}}: P P_{\mathrm{T}}=100 \%\left(\right.$ not $P_{\mathrm{C}}: P P_{\mathrm{T}}$ or $\left.I_{\mathrm{C}}: P P_{\mathrm{T}}\right)$ is consistent with the above conclusion that only $R$ can be used as a metric for assessing trophic conditions or comparing foodweb compartments.

Table 6 gives the modeled input flows and selected output flows for the different steps of our model. Values in the table show that with an increase in the number of food-web links (i.e. from Step 1 through 7) there are generally increases in the ingestion and production of the heterotrophic community (i.e. $I_{\mathrm{C}}: P P_{\mathrm{T}}$ and $\left.P_{\mathrm{C}}: P P_{\mathrm{T}}\right)$, and strong increases in the percentage of $P P_{\mathrm{T}}$ channeled to bacterial $P$ and $R$ (i.e. $P_{\mathrm{b}}: P P_{\mathrm{T}}, R_{\mathrm{b}}: P P_{\mathrm{T}}$ ) and the heterotrophic production of DOC (i.e. $P_{\mathrm{DOC}}: P P_{\mathrm{T}}=$ $\left.E_{\mu z}: P P_{\mathrm{T}}+E_{\mathrm{mz}}: P P_{\mathrm{T}}+D_{\mathrm{b}}: P P_{\mathrm{T}}\right)$. Increases in food-web properties $I, A$, and $P$ reflect increased recycling of car-

Table 6. Modeled input flows for the total heterotrophic community $\left(I_{\mathrm{C}}, A_{\mathrm{C}}\right)$, selected output flows for the total heterotrophic community $\left(P_{\mathrm{C}}\right)$, BACT $\left(P_{\mathrm{b}}, R_{\mathrm{b}}\right)$, and $\mu \mathrm{ZOO}\left(P_{\mu \mathrm{z}}, R_{\mathrm{\mu z}}, E_{\mathrm{\mu z}}\right)$, and heterotrophic DOC production $\left(P_{\mathrm{DOC}}=E_{\mu \mathrm{z}}+E_{\mathrm{mz}}+D_{\mathrm{b}}\right)$ at $15^{\circ} \mathrm{C}$ for the different steps of the steady-state food-web model illustrated in Fig. 3 and described in Table 4 and the associated Electronic Appendix 1 (available at www.int-res.com/articles/suppl/m365p289_app.pdf). Each flow is expressed as a fraction of $P P_{\mathrm{T}}$. At Step 7, there are 5 versions of the model, corresponding to the extreme microbial, microbial, multivorous, herbivorous, and extreme herbivorous food webs (the difference in parameterization among the 5 food webs is their respective flows from $\mathrm{PHYTO} / \mathrm{POC}$ to $\mathrm{MZOO}$ and to $\mu \mathrm{ZOO}$; see the bottom 2 rows of Table A2 in Appendix 1

\begin{tabular}{|c|c|c|c|c|c|c|c|c|c|}
\hline Model & $I_{\mathrm{C}}$ & $A_{\mathrm{C}}$ & $P_{\mathrm{C}}$ & $P_{\mathrm{b}}$ & $R_{\mathrm{b}}$ & $P_{\mu \mathrm{z}}$ & $R_{\mu \mathrm{z}}$ & $E_{\mu \mathrm{z}}$ & $P_{\mathrm{DOC}}$ \\
\hline 1 & 1.00 & 1.00 & 0.00 & 0.00 & 0.20 & 0.00 & 0.00 & 0.00 & 0.00 \\
\hline 2 & 1.23 & 1.23 & 0.23 & 0.00 & 0.20 & 0.23 & 0.29 & 0.00 & 0.00 \\
\hline 3 & 1.36 & 1.36 & 0.36 & 0.00 & 0.20 & 0.23 & 0.29 & 0.00 & 0.00 \\
\hline 4 & 1.43 & 1.43 & 0.43 & 0.04 & 0.16 & 0.25 & 0.31 & 0.00 & 0.00 \\
\hline 5 & 1.70 & 1.70 & 0.50 & 0.09 & 0.31 & 0.27 & 0.13 & 0.20 & 0.20 \\
\hline 6 & 1.82 & 1.82 & 0.53 & 0.11 & 0.38 & 0.28 & 0.14 & 0.21 & 0.29 \\
\hline Step 7-extr. microb. & 2.22 & 2.08 & 0.69 & 0.15 & 0.52 & 0.43 & 0.21 & 0.31 & 0.47 \\
\hline Step 7-microbial & 2.19 & 2.03 & 0.66 & 0.14 & 0.52 & 0.39 & 0.19 & 0.29 & 0.46 \\
\hline Step 7-multivorous & 2.11 & 1.91 & 0.60 & 0.14 & 0.49 & 0.30 & 0.14 & 0.22 & 0.43 \\
\hline Step 7-herbivorous & 1.98 & 1.72 & 0.49 & 0.13 & 0.46 & 0.15 & 0.07 & 0.11 & 0.39 \\
\hline Step 7-extr. herb. & 1.89 & 1.60 & 0.42 & 0.12 & 0.44 & 0.05 & 0.03 & 0.04 & 0.36 \\
\hline
\end{tabular}


bon within the food web. Overall, the increase in the number of food-web links is accompanied by an increase in the channeling of organic carbon to bacteria, which leads to an increase in $R_{\mathrm{b}}: P P_{\mathrm{T}}$. Interestingly, there is a positive relationship between $A_{\mathrm{C}}: P P_{\mathrm{T}}$ and $P_{\mathrm{DOC}}: P P_{\mathrm{T}}$ (Pearson's $\mathrm{r}=+0.91$ ), which suggests that $A_{\mathrm{C}}: P P_{\mathrm{T}}$ can be used as a general index of the fraction of carbon recycled in a food web.

Bacteria dominate the cycling of organic carbon in pelagic marine and freshwater environments, and account for a large fraction of heterotrophic community respiration (Sherr \& Sherr 1996, Rivkin \& Legendre 2002, Robinson \& Williams 2005). Our model results (Table 6) show that, without changing the model parameters for bacteria (i.e. their physiological characteristics), the contribution of bacteria to heterotrophic community respiration more than doubles with an increase in food-web complexity, i.e. when the zooplankton and bacterial food chains are connected, and the number of food-web links within the ecosystem increases. Hence, the complexity of pelagic food webs and their feedbacks can account, in part, for the major role of bacteria in carbon cycling.

The modeled flows corresponding to the 5 food webs (bottom half of Table 6) show that the relative fractions of $P P_{\mathrm{P}}$ grazed by $\mu \mathrm{ZOO}$ and MZOO (which is the only difference among the 5 food webs in our model) have only a small effect on $P_{\mathrm{b}}, R_{\mathrm{b}}$, and $P_{\mathrm{DOC}}$. The values for $P_{\text {DOC }}$ in Table 6 partly reflect different recycling of carbon within the 5 food webs, and do not include viral lysis (see below). For the 5 food webs, $P_{\mathrm{DOC}}$ is $\geq 0.36$, indicating that heterotrophic activity channels 35 to $45 \%$ of $P P_{\mathrm{T}}$ (e.g. 45 to $55 \%$ of $P P_{\mathrm{P}}$, with $P P_{\mathrm{P}}: P P_{\mathrm{T}}=0.8$ ) into the DOC pool (which, in turn, fuels BACT).

Our model results show the importance of the complex network of food-web links in the channeling of organic carbon through bacteria in pelagic environments. One of the key mechanisms is the channeling of organic carbon to bacteria by eukaryotic heterotrophs (45 to $55 \%$ of $P P_{\mathrm{T}}$ compared with $20 \%$ supplied directly by phytoplankton, i.e. $P P_{\mathrm{D}}: P P_{\mathrm{T}}$ also see Jumars et al. 1989, Nagata 2000).

\section{Effects of DOC release from bacteria on the model}

Recent studies suggest that up to half of bacterial mortality may be mediated by viruses, and that the DOC released is assimilated by bacteria (Middelboe et al. 2003). Steady-state food-web models have been used to explore the effects of viral lysis on carbon flows within aquatic food webs. For example, Fuhrman (1992) compared a food web without viruses to an otherwise identical food web with viruses that caused $50 \%$ of the bacterial mortality. The model assumed that only bacteria were infected, and that they consumed all the organic matter released by viral lysis. In a modification of that model, Fuhrman (1999) included viral infection of phytoplankton (causing a $7 \%$ loss), and also flagellate grazing $3 \%$ of viral production. Wilhelm \& Suttle (1999) modified the food-web model of Jumars et al. (1989), assuming that viral lysis caused a 2 to $10 \%$ loss of carbon production from phytoplankton and 20 to $30 \%$ from bacterioplankton. These studies concluded that viral lysis shunted organic matter from bacteria (and phytoplankton) towards DOC, with a corresponding decrease in the transfer of carbon to metazoans. Suttle (2005) concluded that a net effect of the 'viral shunt' is to convert POC into DOC, resulting in more carbon being respired in oceanic surface waters.

Results of two of the published models (Fuhrman 1992, 1999) and from our model (below) are summarized in Table 7, which shows that an implicit assumption of Fuhrman's models is that $R_{\mathrm{b}}: A_{\mathrm{b}}$ was the same both in the absence and in the presence of viral lysis [i.e. these models used constant $\mathrm{BGE}_{2}=\left(P_{\mathrm{b}}+L_{\mathrm{b}}\right):\left(P_{\mathrm{b}}+\right.$ $\left.R_{\mathrm{b}}+L_{\mathrm{b}}\right) ;$ Eq. 10]. When we applied this assumption to our model (Fig. 4), viral lysis of bacteria resulted in a $37 \%$ decrease in $P_{\mathrm{b}}$ and $5 \%$ increase in $R_{\mathrm{b}}$ for the 5 food webs (shown in Table A4 of Electronic Appendix 1; values of modeled flows for the multivorous food web are given in Table 7, as example), a result which is consistent with those of Fuhrman (1992, 1999).

We assessed the influence of an invariant $R_{\mathrm{b}}: A_{\mathrm{b}}$ on the modeled food-web effects of viruses by running

Table 7. Carbon flows from the BACT compartment, expressed as a fraction of $P P_{\mathrm{T}}$ (i.e. $P_{\mathrm{b}}: P P_{\mathrm{T}}, R_{\mathrm{b}}: P P_{\mathrm{T}}$, and $L_{\mathrm{b}}: P P_{\mathrm{T}}$ ), and 3 ratios of these flows, in different biogeochemical food-web models without (first value in each cell of the table) and with (second value) viral lysis. $A_{\mathrm{b}}=P_{\mathrm{b}}+R_{\mathrm{b}}+L_{\mathrm{b}}$ (Eq. 4). Values given for our own model (i.e. 'present study') are those we computed under 2 different assumptions [i.e. constant $R_{\mathrm{b}}: A_{\mathrm{b}}$ and constant $P_{\mathrm{b}}:\left(P_{\mathrm{b}}+R_{\mathrm{b}}\right)$ ] for the multivorous food web (Model Step 7), at $15^{\circ} \mathrm{C}_{;}$corresponding values for the 5 planktonic food webs are given in Table 6 and Tables A4 \& A5 of Electronic Appendix 1 (available at www.int-res.com/articles/suppl/m365p289_app.pdf)

\begin{tabular}{|c|c|c|c|c|c|c|}
\hline Model & $P_{\mathrm{b}}: P P_{\mathrm{T}}$ & $R_{\mathrm{b}}: P P_{\mathrm{T}}$ & $L_{\mathrm{b}}: P P_{\mathrm{T}}$ & $P_{\mathrm{b}}:\left(P_{\mathrm{b}}+R_{\mathrm{b}}\right)$ & $P_{\mathrm{b}}: A_{\mathrm{b}}$ & $R_{\mathrm{b}}: A_{\mathrm{b}}$ \\
\hline Fuhrman (1992) & $0.30-0.19$ & $0.30-0.38$ & $0-0.19$ & $0.50-0.33$ & $0.50-0.25$ & $0.50-0.50$ \\
\hline Fuhrman (1999) & $0.30-0.20$ & $0.30-0.40$ & $0-0.20$ & $0.50-0.40$ & $0.50-0.20$ & $0.50-0.50$ \\
\hline Present study: constant $R_{\mathrm{b}}: A_{\mathrm{b}}$ & $0.14-0.09$ & $0.49-0.52$ & $0-0.06$ & $0.22-0.15$ & $0.22-0.13$ & $0.78-0.78$ \\
\hline Present study: constant $P_{\mathrm{b}}:\left(P_{\mathrm{b}}+R_{\mathrm{b}}\right)$ & $0.14-0.14$ & $0.49-0.49$ & $0-0.09$ & $0.22-0.22$ & $0.22-0.20$ & $0.78-0.71$ \\
\hline
\end{tabular}


our model with the assumption that $\mathrm{BGE}_{1}$ was the same both in the absence and in the presence of viral lysis $\left[\mathrm{BGE}_{1}=P_{\mathrm{b}} /\left(P_{\mathrm{b}}+R_{\mathrm{b}}\right)\right.$; Eq. 9]. The difference between the 2 assumptions is that, in the first case, the field-estimated synthesis of bacterial biomass $=P_{\mathrm{b}}+L_{\mathrm{b}}$, hence constant $\mathrm{BGE}_{2}$ and $R_{\mathrm{b}}:\left(P_{\mathrm{b}}+R_{\mathrm{b}}+L_{\mathrm{b}}\right)$, whereas, in the second case, the field-estimated synthesis of bacterial biomass $=P_{\mathrm{b}}$, hence constant $\mathrm{BGE}_{1}$. The first case assumes that the effect of viral lysis is not included in either measured $P_{\mathrm{b}}$ or BGE used in models, whereas the second assumes that the effect of viral lysis is included in both measured $P_{\mathrm{b}}$ (Eq. A32) and BGE used in models. The resulting modeled flows are given in Electronic Appendix 1 (Table A5), for the 5 food webs, and in Table 7 , for the multivorous food web. With a constant $\mathrm{BGE}_{1}$, viral lysis did not influence any modeled output flow (e.g. $P_{\mathrm{b}}: P P_{\mathrm{T}}$ and $R_{\mathrm{b}}: P P_{\mathrm{T}}$ ), except $L_{\mathrm{b}}: P P_{\mathrm{T}}$, which was present only in models with viral lysis, and the flow of DOC to BACT was higher in models with lysis (compare values in Table 6 and Table A5). The reason for the constancy of output flows is that, in corresponding model runs, the loss of bacterial carbon resulting from lysis (i.e. $L_{\mathrm{b}}: P P_{\mathrm{T}}$ ) was compensated exactly by an increase in the flow of DOC to BACT (i.e. $A_{\mathrm{b}}: P P_{\mathrm{T}}$ ).

The above results show that the modeled effects of viral lysis on food-web cycling of organic carbon depend on the assumptions used in building the models. With one type of model formulation (Table 7 : Fuhrman 1992, 1999, and 'present study: constant $R_{\mathrm{b}}: A_{\mathrm{b}}{ }^{\prime}$ ), viral lysis influenced modeled output flows, whereas with another formulation [Table 7: 'present study: constant $\left.P_{\mathrm{b}}:\left(P_{\mathrm{b}}+R_{\mathrm{b}}\right)^{\prime}\right]$, lysis did not influence the modeled flows.

The effect of non-viral extracellular release of DOC by bacteria, which was considered above (i.e. Eq. 12), could be added to the DOC released by lysis (i.e. $L_{\mathrm{b}}$ ) in our models by changing the values of bacterial lysis parameters. This approach would be reasonable if all

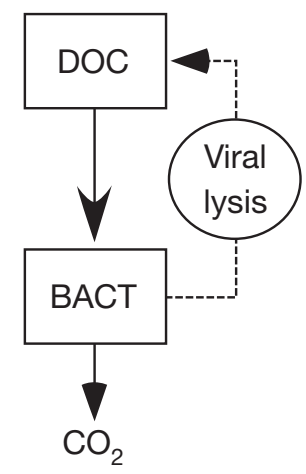

Fig. 4. 'Lysis loop' added to Step 7 of the model developed in Figs. 1a \& 3, to explore the effects of viral lysis on steady-state planktonic food webs of the DOC from extracellular release were used by bacteria with a similar efficiency. This assumption may be overly simplistic as some of that DOC appears to be refractory (Kawasaki \& Benner 2006).

\section{Effects of phytodetritus on the model}

Although phytodetritus that is produced in the euphotic zone generally rapidly sinks, a fraction may be consumed where it is produced. Because our model considers the fate of non-exported $P P$, we examined only the role of the non-exported phytodetritus. To do so, we assumed that $20 \%$ of $P P_{\mathrm{P}}$ was transferred to phytodetritus (i.e. DETR), and $80 \%$ was consumed directly by $\mu \mathrm{ZOO}$ and MZOO. Differences between the various food-web models with or without production of phytodetritus were small, with the organic carbon diverted from $\mu \mathrm{ZOO}$ and MZOO to DETR mainly flowing to BACT. Values of modeled flows for the 5 planktonic food webs are given in Electronic Appendix 1 (Table A7).

Given that including viral lysis (with the same $\mathrm{BGE}_{1}$ in the absence and in the presence of lysis) and the production of phytodetritus in our model had only a small influence on the results (with constant $R_{\mathrm{b}}: A_{\mathrm{b}}$, viral lysis influenced modeled output flows), for simplicity, these 2 processes are not considered further in our model.

\section{Sensitivity analysis}

The sensitivity of modeled flows to the values of key parameters is assessed in Electronic Appendix 1 (Table A8). Each of these parameters for BACT (i.e. BGE), $\mu \mathrm{ZOO}$ [i.e. $\mathrm{GGE}_{\mu z}$, and $\mathrm{E}_{\mu z} /\left(\mathrm{E}_{\mu z}+\mathrm{R}_{\mu z}\right)$ ], and MZOO [i.e. $\mathrm{NGE}_{\mathrm{mz}}, \mathrm{AE}_{\mathrm{mz}} \times \mathrm{E}_{\mathrm{mz}} /\left(\mathrm{E}_{\mathrm{mz}}+\mathrm{R}_{\mathrm{mz}}\right)$, and $\mathrm{AE}_{\mathrm{mz}}$ ] was increased and then decreased by $20 \%$ of the initially assigned values. Most modeled flows were quite insensitive to changes in parameter values, and few showed a difference $\geq 15 \%$. The model is most sensitive to the value of $\mathrm{AE}_{\mathrm{mz}}$ and least sensitive to the value of $\mathrm{NGE}_{m z}$ in the following order: $\mathrm{AE}_{\mathrm{mz}}>\mathrm{E}_{\mu \mathrm{z}} /\left(\mathrm{E}_{\mu z}+\mathrm{R}_{\mu z}\right)$ $>\mathrm{BGE}>\mathrm{GGE}_{\mu \mathrm{z}}>\mathrm{AE}_{\mathrm{mz}} \times \mathrm{E}_{\mathrm{mz}} /\left(\mathrm{E}_{\mathrm{mz}}+\mathrm{R}_{\mathrm{mz}}\right)>\mathrm{NGE}_{\mathrm{mz}}$.

We discussed above the effects of viral lysis of bacteria on modeled flows (Section 'Model effects of DOC release from bacteria'). Table 7 (second row from the bottom) and Table A4 in Electronic Appendix 1 show that when the model was run under the assumption of constant $R_{\mathrm{b}}: A_{\mathrm{b}}, P_{\mathrm{b}}$ was sensitive to the inclusion of $L_{\mathrm{b}}$. When the model was run under the assumption of constant $P_{\mathrm{b}}:\left(P_{\mathrm{b}}+R_{\mathrm{b}}\right)$, Table A9 in Electronic Appendix 1 shows that all modeled flows (except $L_{\mathrm{b}}$ ) were not very sensitive (i.e. difference $<15 \%$ ) to changes in the value 
of parameter 'bacterial lysis mortality factor' $=L_{\mathrm{b}}:\left(P_{\mathrm{b}}+\right.$ $L_{\mathrm{b}}$ ) (Eq. A18). In the present study, we ran our model with the assumption of constant $P_{\mathrm{b}}:\left(P_{\mathrm{b}}+R_{\mathrm{b}}\right)$, in which case the modeled flows are not sensitive to the inclusion of $L_{\mathrm{b}}$, as shown above.

\section{THE MICROBIAL HUB APPROACH}

\section{Central role of the microbial hub}

The above analysis shows that heterotrophic microbes are central to the cycling of biogenic carbon within planktonic food webs for the following reasons. Firstly, BACT and $\mu \mathrm{ZOO}$ assimilate $P P_{\mathrm{D}}$ and ingest $P P_{\mathrm{P}}$, respectively. Secondly, the network of linkages channels, in our steady-state model, up to $35-45 \%$ of $P P_{\mathrm{T}}$ (and up to $45-55 \%$ of $P P_{\mathrm{P}}$ ) into the DOC pool, and thus towards bacteria (Table 6, last column). Finally, BACT and $\mu \mathrm{ZOO}$ remineralize most of the organic carbon they assimilate, with their combined respiration often exceeding $70 \%$ of $P P_{\mathrm{T}}$ (Table 3 ); the remainder of the organic carbon is transferred to MZOO and LARGE. This leads us to propose that heterotrophic microbes within the planktonic food web constitute the HUB, into which organic carbon is channeled and from which carbon is redirected towards $\mathrm{CO}_{2}$ (respiration) and metazoans. MZOO also can have a significant role in carbon dynamics, i.e. according to the food-web type; these organisms can consume directly a large fraction of $P P_{\mathrm{P}}$ (e.g. in the herbivorous food web, MZOO consume directly $75 \%$ of $P P_{\mathrm{P}}$, a value based on field observations, see above; assuming that, $P P_{\mathrm{P}}: P P_{\mathrm{T}}=$ 0.8 , the previous value corresponds to $60 \%$ of $P P_{\mathrm{T}}$ ).

As was developed in the 'Introduction', heterotrophic microbes and metazoans have different effects on euphotic-zone respiration. These differences depend on both biological characteristics of the organisms and the structure of the food web. For example, Legendre \& Michaud (1998) reported a positive relationship between the body size of marine pelagic organisms and the minimum turnover time of biogenic carbon incorporated in their bodies, and a negative relationship between body size and the residence time of fecal pellets above the depth of carbon sequestration in the ocean. Moreover, an increase in food-web complexity and feedbacks appears to account for the major role of bacteria in organic carbon cycling within pelagic ecosystems. These 2 factors contribute to the distinct characters of pelagic microbes and metazoans.

In the present section, we propose to restructure our food-web model around the heterotrophic microbial and the metazoan compartments (i.e. the HUB and METAZ, respectively). In the microbial-hub approach (Figs. 1b \& 5c, and described below), we combine
BACT and $\mu \mathrm{ZOO}$ into the HUB, and group MZOO and LARGE into METAZ.

Our original model (Fig. 5a) had 7 compartments and 15 flows $\left(P P_{\mathrm{P}}\right.$ is not counted as a separate organic carbon flow, because it is the sum of $P P_{\mathrm{P} \mu \mathrm{x}}$ and $\left.P P_{\mathrm{Pmx}}\right)$. The microbial-hub version of the model (Fig. 5c) contains 3 compartments and 5 summary flows. We explain below how we used the 15 modeled flows in the original model to compute the 5 summary flows in the microbial-hub version of the model.

Fig. 5 shows the sequential restructuring of our original model (Fig. 5a) through an intermediate structure (Fig. 5b), to the microbial-hub version of the model (Fig. 5c) with the 5 summary flows. In the simplified model (Fig. 5b), 2 of the flows from the original model (Fig. 5a) are internal to the HUB (i.e. $P_{\mathrm{b}}, E_{\mu \mathrm{z}}$ ), and 3 are internal to METAZ (i.e. $P_{\mathrm{mz}}, F_{\mathrm{mz}}, D_{\mathrm{mz}}$ ); the same flows are internal to the same compartments in the microbial-hub version of the model (Fig. 5c). Fig. 5b and $\mathrm{C}$ show the central position occupied by the HUB in the planktonic food web, and its dual role in receiving organic carbon from both PHYTO and the heterotrophic food web, and redirecting that carbon towards $\mathrm{CO}_{2}$ and METAZ. Within the euphotic zone, the organic carbon originating from $P P_{\mathrm{T}}$ is progressively recycled by heterotrophs and ultimately respired or exported. The food-web processes that lead from $P P_{\mathrm{T}}$ to $R_{\mathrm{C}}$ (in our model $R_{\mathrm{C}}=P P_{\mathrm{T}}$ ) include $P, E, F$, and $D$. Since all these are non-additive food-web processes, quantifying the roles of food-web components with respect to organic carbon cycling toward $R_{\mathrm{C}}$ requires transforming and combining $P, E, F$, and $D$ into $R$ flows. Hence, our analysis quantifies the cycling of organic carbon by HUB and METAZ using $R$ as the unifying metric, i.e. the 5 summary flows in the microbial-hub version of the model are $R$.

Fig. $5 \mathrm{c}$ shows the 5 summary flows in relation to the 3 food-web compartments. In Fig. 5c (which considers the fate of $P P_{\mathrm{T}}$ within the euphotic zone only), all $P P_{\mathrm{T}}$ is respired by METAZ and HUB (i.e. $R_{\text {met }}$ and $R_{\text {hub }}$ respectively); hence, $\left(R_{\text {met }}+R_{\text {hub }}\right)=R_{\mathrm{C}}=P P_{\mathrm{T}}$. The direct channeling of $P P_{\mathrm{T}}$ toward $R_{\mathrm{C}}$ by METAZ and HUB is $R_{\text {met }}\left(P P_{\mathrm{T}}\right)$ and $R_{\text {hub }}\left(P P_{\mathrm{T}}\right)$, respectively. Finally, $R_{\text {met }}($ hub $)$ is the difference between the channeling of carbon by HUB toward $R_{\text {met }}$ and by METAZ toward $R_{\text {hubi hence, }}$ $R_{\text {met }}$ (hub) can be positive or negative. Electronic Appendix 1 provides the equations to calculate the 5 summary $R$ flows, using values of $P P$ and modeled flows from the original model (Eqs. A27 to A31).

\section{Summary respiration flows}

Table 8 gives the values of the 5 summary $R$ flows calculated for the 5 planktonic food webs at $15^{\circ} \mathrm{C}$. The 
(a) Original model (Fig. 1a)

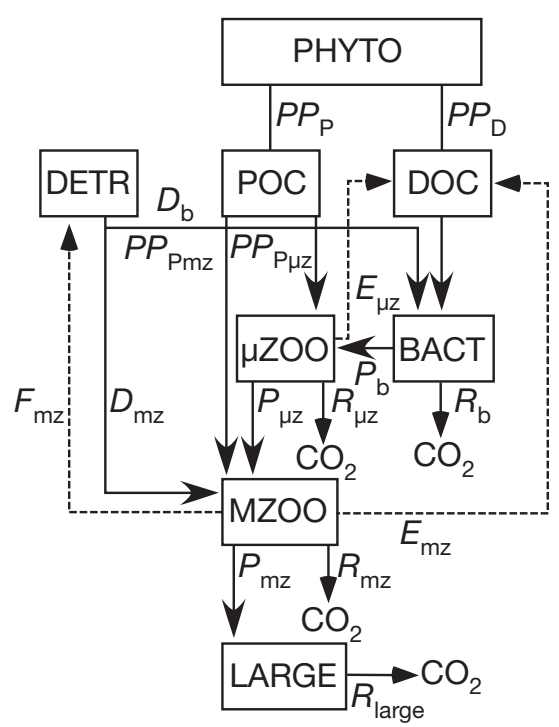

(b) Simplified model

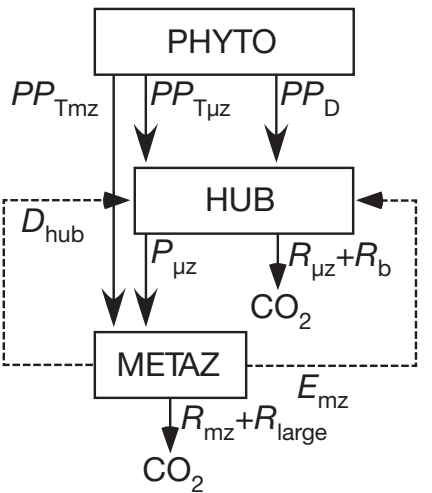

(c) Microbial-hub version of the model

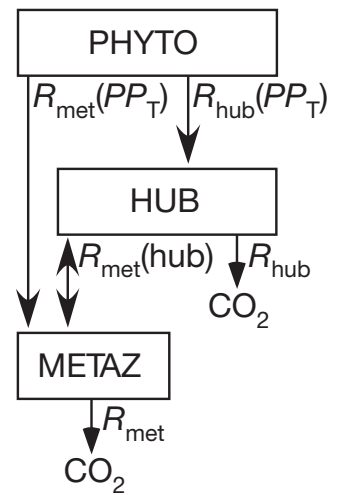

Fig. 5. Development of a microbial-hub version of: (a) the original steady-state model shown in Figs. 1a \& 3 (Step 7 ); (b) simplified model with PHYTO/POC and PHYTO/DOC merged into phytoplankton, BACT and $\mu$ ZOO combined into the HUB, MZOO and LARGE grouped in METAZ, and the same flows as in the original model (some have become internal to compartments, see below); and (c) microbial-hub version of the model, with 5 summary flows. In the latter 2 versions of the model, 2 flows that were in the original model are internal to the HUB $\left(P_{\mathrm{b}}, E_{\mathrm{pz}}\right)$, and 3 are internal to METAZ $\left(P_{\mathrm{mz}}, F_{\mathrm{mz}}, D_{\mathrm{mz}}\right)$. All flows are specified for each version of the model (for the microbial-hub version, see Eqs. (A27) to (A31) of Electronic Appendix 1, available at www.int-res.com/articles/suppl/m365p289_app.pdf). Solid arrows: forward flows; dashed arrows: backward flows; double-headed arrow: net flow possible in both directions

table shows that for the 5 different food-web structures, the HUB channels directly 20 to $100 \%$ of $P P_{\mathrm{T}}$ toward $R_{\mathrm{C}}\left[R_{\mathrm{hub}}\left(P P_{\mathrm{T}}\right)\right]$, and respires 46 to $73 \%$ of $P P_{\mathrm{T}}$ $\left(R_{\text {hub }}\right)$. Conversely, METAZ channels directly 0 to $80 \%$ of $P P_{\mathrm{T}}$ toward $R_{\mathrm{C}}\left(R_{\mathrm{met}}\left(P P_{\mathrm{T}}\right)\right.$, and respires 27 to $54 \%$ of $P P_{\mathrm{T}}\left(R_{\mathrm{met}}\right)$. In the previous 2 sentences, the values 20 to $100 \%$ for the HUB and the corresponding values 0 to $80 \%$ for METAZ correspond to the 2 extreme food webs (i.e. extreme herbivorous and extreme microbial). The extreme herbivorous and herbivorous food webs show negative $R_{\text {met }}($ hub) values, indicating that the HUB channels less carbon toward $R_{\text {met }}$ than

Table 8. Channeling of the organic carbon originating from $P P_{\mathrm{T}}$ towards $R_{\mathrm{C}}$ by HUB and METAZ. Each value is expressed as a fraction of $R_{\mathrm{C}}$. The 5 flows are described in the section 'Central role of the microbial hub' [because $R_{\text {met }}($ hub) represents the difference between the transfer of carbon from HUB toward METAZ $R$, and from METAZ toward HUB $R$, it can be positive or negative]. Values in the table correspond to model runs for the 5 planktonic food webs (Model Step 7) at $15^{\circ} \mathrm{C}$

\begin{tabular}{|lccccc|}
\hline Food web & $R_{\mathrm{hub}}\left(P P_{\mathrm{T}}\right)$ & $R_{\mathrm{hub}}$ & $R_{\mathrm{met}}(\mathrm{hub})$ & $R_{\mathrm{met}}\left(P P_{\mathrm{T}}\right)$ & $R_{\mathrm{met}}$ \\
\hline Extreme microbial & 1.00 & 0.73 & 0.27 & 0.00 & 0.27 \\
Microbial & 0.92 & 0.71 & 0.21 & 0.08 & 0.29 \\
Multivorous & 0.72 & 0.64 & 0.08 & 0.28 & 0.36 \\
Herbivorous & 0.40 & 0.53 & -0.13 & 0.60 & 0.47 \\
Extreme herbivorous & 0.20 & 0.46 & -0.26 & 0.80 & 0.54 \\
\hline
\end{tabular}

METAZ channels carbon toward $R_{\text {hub }}$. On the progression from microbial toward herbivorous food-web types, there are decreases in the 2 HUB-mediated flows [i.e. $R_{\text {hub }}\left(P P_{\mathrm{T}}\right)$ and $R_{\text {hub }}$, and increases in the 2 METAZ-mediated flows [i.e. $R_{\text {met }}\left(P P_{\mathrm{T}}\right)$ and $R_{\text {met }}$ ], as well as a shift in $R_{\text {met }}($ hub) from net HUB contribution to METAZ $R$ to net METAZ contribution to HUB $R$. Values in Table 8 show that the HUB channels carbon from $P P_{\mathrm{T}}$ toward $R_{\mathrm{C}}$ even when all $P P_{\mathrm{P}}$ is grazed by herbivores (i.e. extreme herbivorous food web). Although the model was run at $15^{\circ} \mathrm{C}$, the patterns are the same at other temperatures.

Using the microbial-hub approach, we examined the temperature-dependence of the summary flows. Table 9 reports values for these flows calculated at 5,15 and $25^{\circ} \mathrm{C}$ for the multivorous food web. The general patterns are the same for the 4 other food webs. Temperature has no effect on $R_{\text {hub }}\left(P P_{\mathrm{T}}\right)$ and $R_{\text {met }}\left(P P_{\mathrm{T}}\right)$, because in our model these flows are determined by the relative consumption of $P P_{\mathrm{P}}$ by $\mu \mathrm{ZOO}$ and MZOO, of which the values were constant (i.e. not temperature dependent) for each food web in our model runs (see Eqs. A29 \& A30 and Table A2 in 
largely dominates euphotic-zone $R$ in most of the world ocean, and that from polar to tropical waters, there is an increase in both HUB $R\left(R_{\text {hub }}\right)$, and the direct HUB channeling of $P P_{\mathrm{T}}$ towards $R_{\mathrm{C}}\left[R_{\mathrm{hub}}\left(P P_{\mathrm{T}}\right)\right]$. Interestingly, there are zonal differences in the HUBmediated channeling of carbon towards METAZ $R$ [ $R_{\text {met }}($ hub)]: (1) in polar waters, the HUB channels less carbon toward $R_{\text {met }}$ than METAZ channels carbon toward $R_{\text {hubi }}$ (2) in temperate waters, the opposite occurs; and (3) in tropical waters, where the METAZmediated $R$ flows are very small, the net exchange of carbon between the HUB and METAZ is close to zero. The results in Table 10 are preliminary, as the key $R$ flows in oceans are still poorly constrained (e.g. Robinson \& Williams 2005). However, the 5 summary $R$ flows in Table 10 (i.e. for the polar, temperate, and tropical zones) are remarkably similar to the modeled flow values in Table 8 for the herbivorous, multivorous, and microbial food webs, respectively [except for $R_{\text {met }}\left(\right.$ hub), and for $R_{\text {met }}$ in the tropical zone/microbial food web], despite the 2 sets of values having been derived independently. This suggests that the relative magnitudes of microbial and metazoan $R$ quantified with the microbial-hub approach correspond to actual properties of pelagic ecosystems, and also that microbial $R$ largely controls the recycling of organic carbon in the euphotic zone.

\section{Effects of climate change on marine pelagic ecosystems}

Climate change will affect a suite of environmental characteristics of the ocean (IPCC 2007). Legendre \& Rivkin (2005) reviewed predicted climate-driven changes in the characteristics of the upper ocean, and their possible effects on pelagic marine ecosystems. The responses of pelagic food webs to 2 of the predicted environmental changes, i.e. increased water temperature and stratification of the upper ocean, are analyzed here using the microbial-hub approach, to illustrate a potential, new application.

Increased water temperatures will alter temperature-dependent characteristics of organisms and ecosystems (references in Legendre \& Rivkin 2005). In our model, temperature-dependent growth efficiencies control the partitioning of ingested (or assimilated) carbon among the flows out of food-web compartments (see Electronic Appendix 1). In addition, increased water-column stratification will cause decreased vertical mixing and nutrient replenishment in the euphotic zone. Coupled climate models predict that decreased vertical mixing and nutrient replenishment will tend to shift marine pelagic food webs towards generally smaller celled phytoplankton (e.g. Bopp et al. 2005), and thus smaller zooplankton. The 5 planktonic food webs in our model differ in the fraction of $P P_{\mathrm{P}}$ consumed directly by $\mu \mathrm{ZOO}$ and $\mathrm{MZOO}$, which, in the ocean, is largely determined by the respective sizes of phytoplankton and zooplankton. Hence, it is expected that increased stratification will tend to shift marine pelagic systems toward the multivorous and microbial food-web types.

Based on the assumption of an increase in water temperature, and shifts of planktonic food webs towards small cells, our model results (summarized in Table 11) predict increased HUB $R$ and direct HUB channeling of $P P_{\mathrm{T}}$ toward $R_{\mathrm{C}}$, decreased METAZ $R$ and direct METAZ channeling of $P P_{\mathrm{T}}$ toward $R_{\mathrm{C}}$, and competing effects of the 2 factors on the exchange of carbon between the HUB and METAZ. Overall, climate change (i.e. here, increased water temperature and stratification of the upper ocean) would increase the contribution of microbes and decrease the contribution of metazoans in marine pelagic community metabolism.

\section{Numerical models}

The microbial-hub approach is not intended as a new biogeochemical/food-web module, to be incorporated in larger numerical models (e.g. general circulation models). Such modules already exist, and new versions are being actively developed (e.g. Le Quéré et al. 2005, Flynn 2006, Le Quéré 2006). Numerical models as well as field observations provide values of $R$ flows, or information from which such flows could be derived. The microbial-hub approach provides a quantitative framework for synthesizing the information on $R$ flows, and using it to compare pelagic ecosystems, or explore key characteristics of food-web metabolism in changing environments.
Table 11. Synthesis of Tables 8 \& 9 assuming a climate-driven increase in water temperature and shifts of planktonic food webs toward small cells. Descriptions in the table indicate whether the selected climate-change-affected variable would increase or decrease the various summary flows, or have no effect

\begin{tabular}{|lccccc|}
\hline $\begin{array}{l}\text { Climate change } \\
\text { effect }\end{array}$ & $R_{\text {hub }}\left(P P_{\mathrm{T}}\right)$ & $R_{\text {hub }}$ & $R_{\text {met }}($ hub $)$ & $R_{\text {met }}\left(P P_{\mathrm{T}}\right)$ & $R_{\text {met }}$ \\
\hline $\begin{array}{l}\text { Temperature } \\
\text { increase (Table 9) }\end{array}$ & No effect & Increase & Decrease & No effect & Decrease \\
$\begin{array}{l}\text { Food-web shifts } \\
\text { toward small cells } \\
\text { (Table 8) }\end{array}$ & Increase & Increase & Increase & Decrease & Decrease \\
\hline
\end{tabular}




\section{CONCLUSIONS}

Our review consolidates information on the functioning of the microbial heterotrophic components of the pelagic food web that have been published in the last decades. We introduce and develop into an operational approach the concept of microbial hub as an evolution and extension of the microbial loop and food web. We use the microbial-hub approach to analyze a wide range of food webs, different regions of the world ocean, and predicted effects of climate change on oceans, and show that the microbial-hub approach provides a new, powerful tool for exploring pelagic community metabolism.

Some key considerations for future research are as follows. (1) Concerning basic concepts: (1.1) respiration is the only additive property of the ecosystem, and can thus be used as a metric for assessing trophic conditions or comparing food-web compartments; (1.2) given that osmotrophy by bacteria is a dominant pathway of organic carbon remineralization in the sea, the denominator in any computation of the fraction of $P P$ respired must include $P P_{\mathrm{D}}$ as well as $P P_{\mathrm{P}}$. (2) Concerning work at sea and in the laboratory, there is need, in different regions of the world ocean and at different seasons: (2.1) to measure $P P_{\mathrm{D}} / P P_{\mathrm{T}}$ (2.2) to measure the respiration flows of major food-web compartments; (2.3) to quantify the fraction of $P P_{\mathrm{P}}$ grazed by micro- and larger zooplankton (including microphagous macrozooplankton); (2.4) to document and parameterize the food-web and biogeochemical characteristics of Archaea, e.g. metagenomics could be a powerful approach to achieve this objective; (2.5) to quantify the release of DOC from bacteria (by viral lysis, and possibly extracellular release), and assess its effects on estimates of $\mathrm{BGE}_{i}(2.6)$ to better estimate the growth efficiencies of the food-web compartments considered in models, as a function of environmental variables (e.g. temperature, resource concentration); (2.7) to better characterize food-web processes and carbon flows in the mesopelagic layer of the ocean (e.g. Legendre \& Rivkin 2005). (3) Concerning models: (3.1) the effects of introducing viral lysis or a viral compartment on food-web flows must be thoroughly investigated; (3.2) outputs of food-web/biogeochemical models must be synthesized and compared among models and to field observations, e.g. using the summary respiration flows of the microbial-hub approach.

Acknowledgements. This research was supported by funding from CNRS and the Université Pierre et Marie Curie, France, to the Laboratoire d'Océanographie de Villefranche (L.L.), and by grants from the Natural Sciences and Engineering Research Council of Canada to R.B.R. We thank Dr. Evelyn B. Sherr and anonymous reviewers for very insightful comments and suggestions, Drs. L. Bopp, C. Suttle, and S. W. Wilhelm for information and insights, and Dr. S. Pesant for detailed comments and suggestions on an earlier version of the manuscript.

\section{LITERATURE CITED}

Anderson TR (2005) Plankton functional type modelling: Running before we can walk? J Plankton Res 27:1073-1081

- Anderson TR, Ducklow HW (2001) Microbial loop carbon cycling in ocean environments studied using a simple steady-state model. Aquat Microb Ecol 26:37-49

Arenovski AL, Lim EL, Caron DA (1995) Mixotrophic nanoplankton in oligotrophic surface waters of the Sargasso Sea may employ phagotrophy to obtain major nutrients. J Plankton Res 17:801-820

Azam F, Malfatti F (2007) Microbial structuring of marine ecosystems. Natl Rev 5:782-791

Azam F, Smith DC (1991) Bacterial influence on the variability in the ocean's biogeochemical state: a mechanistic view. In: Demers S (ed) Particle analysis in oceanography. NATO ASI Series, Vol G27. Springer Verlag, Heidelberg, p 213-239

Azam F, Fenchel T, Field JG, Gray JS, Meyer-Reil LA, Thingstad $F$ (1983) The ecological role of water-column microbes in the sea. Mar Ecol Prog Ser 10:257-263

Bopp L, Aumont O, Cadule P, Alvain S, Gehlen M (2005) Response of diatoms distribution to global warming and potential implications: a global model study. Geophys Res Lett 32:L19606

Bushaw KL, Zepp RG, Tarr MA, Schulz-Jander D and others (1996) Photochemical release of biologically available nitrogen from aquatic dissolved organic matter. Nature 381:404-407

Calbet A, Landry MR (2004) Phytoplankton growth, microzooplankton grazing, and carbon cycling in marine systems. Limnol Oceanogr 49:51-57

Castellani C, Irigoien X, Harris R, Lampitt R (2005) Feeding and egg production of Oithona similis in the North Atlantic. Mar Ecol Prog Ser 288:173-182

Cottrell MT, Kirchman DL (2000) Natural assemblages of marine proteobacteria and members of the CytophagaFlavobacter cluster consuming low- and high-molecularweight dissolved organic matter. Appl Environ Microbiol 66:1692-1697

Cushing DH (1989) A difference in structure between ecosystems in strongly stratified waters and in those that are only weakly stratified. J Plankton Res 11:1-13

del Giorgio PA, Cole JJ (2000) Bacterial energetics and growth efficiency. In: Kirchman DL (ed) Microbial ecology of the oceans. Wiley-Liss, New York, p 289-325

> DeLong EF (2006) Archaeal mysteries of the deep revealed. Proc Natl Acad Sci USA 103:6417-6418

Engel A, Thoms S, Riebesell U, Rochelle-Newall E, Zondervan I (2004) Polysaccharide aggregation as a potential sink of marine dissolved organic carbon. Nature 428:929-932

Fasham MJR (1985) Flow analysis of materials in the marine euphotic zone. In: Ulanowicz RE, Platt T (eds) Ecosystem theory for biological oceanography. Can Bull Fish Aquat Sci 213:139-162

Flynn KJ (2006) Reply to horizons article 'Plankton functional type modelling: Running before we can walk?' Anderson 2005. II. Putting trophic functionality into plankton functional types. J Plankton Res 28:873-875

Fortier L, Le Fèvre J, Legendre L (1994) Export of biogenic carbon to fish and to the deep ocean: the role of large planktonic microphages. J Plankton Res 16:809-839

Fuhrman JA (1992) Bacterioplankton roles in cycling of organic matter: the microbial food web. In: Falkowski PG, Woodhead AD (eds) Primary productivity and biogeochemical cycles in the sea. Plenum, New York, p 361-383 Fuhrman JA (1999) Marine viruses and their biogeochemical 
and ecological effects. Nature 399:541-548

Fuhrman JA, Noble RT (1996) Viruses and protists cause similar bacterial mortality in coastal seawater. Limnol Oceanogr 40:1236-1242

Fuhrman JA, Schwalbach M (2003) Viral influence on aquatic bacterial communities. Biol Bull 204:192-195

$>$ Fuhrman JA, Hewson I, Schwalback MS, Steele JA, Brown MV, Naeem S (2006) Annual recurring bacterial communities are predictable from ocean conditions. Proc Natl Acad Sci USA 103:13104-13109

Gray JS, Field JG, Azam F, Fenchel T, Meyer-Reil LA, Thingstad F (1984) The role of free bacteria and bactivory. In: Fasham MJR (ed) Flows of energy and materials in marine ecosystems. Theory and practice. Plenum, New York, p 707-723

> Herndl GJ, Reinthaler T, Teira E, Van Aken H, Veth C, Pernthaler A, Pernthaler J (2005) Contribution of Archaea to total prokaryotic production in the deep Atlantic Ocean. Appl Environ Microbiol 71:2303-2309

Hobbie JE, Holm-Hansen O, Packard TT, Pomeroy LR, Sheldon RW, Thomas JP, Wiebe WJ (1972) A study of the distribution and activity of microorganisms in ocean water. Limnol Oceanogr 17:544-555

Ikeda T, Kanno Ozaki YK, Shinada A (2001) Metabolic rates of epipelagic marine copepods as a function of body mass and temperature. Mar Biol 139:587-596

IPCC (Intergovernmental Panel on Climate Change) (2007) Climate change 2007: the physical science basis. Summary for policymakers. IPCC Secretariat, Geneva Jackson, GA

Eldridge PM (1992) Food web analysis of a planktonic system off Southern California. Prog Oceanogr 30:223-251

Jensen L, Søndergaard M (1982) Abiotic formation of particles from extracellular organic carbon released by phytoplankton. Microb Ecol 8:47-54

Jones RI (2000) Mixotrophy in planktonic protists: an overview. Freshw Biol 45:219-226

- Jumars PA, Perry DL, Baross JA, Perry MJ, Frost BW (1989) Closing the microbial loop: dissolved carbon pathway to heterotrophic bacteria from incomplete ingestion, digestion and absorption in animals. Deep-Sea Res 36:483-495

Karl DM (2007) Microbial oceanography: paradigms, processes and promise. Natl Rev 5:759-769

Karner MB, DeLong EF, Karl DM (2001) Archaeal dominance in the mesopelagic zone of the Pacific Ocean. Nature 409: 507-510

Kawasaki N, Benner R (2006) Bacterial release of dissolved organic matter during cell growth and decline: molecular origin and composition. Limnol Oceanogr 51:2170-2180

Kirchman DL (ed) (2000) Microbial ecology of the oceans. Wiley-Liss, New York

Kirchman DL (ed) (2008) Microbial ecology of the oceans, 2nd edn. Wiley, New York (in press)

Kirchman DL, Elifantz H, Dittel AI, Malmstrom RR, Cottrell MT (2007) Standing stocks and activity of Archaea and Bacteria in the western Arctic Ocean. Limnol Oceanogr 52:495-507

Langenheder S, Lindström ES, Tranvik LJ (2005) Weak coupling between community composition and functioning of aquatic bacteria. Limnol Oceanogr 50:957-967

Laybourn-Parry J, James MR, McKnight DM, Priscu J, Spaulding SaA, Shiel R (1996) The microbial plankton of Lake Fryxell, southern Victoria Land, Antarctica during the summers of 1992 and 1994. Polar Biol 17:54-61

Le Quéré C (2006) Reply to horizons article 'Plankton functional type modelling: Running before we can walk?' Anderson 2005. I. Abrupt changes in marine ecosystems? J Plankton Res 28:871-872
Le Quéré C, Harrison SP, Prentice IC, Buitenhuis ET and others (2005) Ecosystem dynamics based on plankton functional types for global ocean biogeochemistry models. Glob Change Biol 11:2016-2040

Legendre L, Michaud J (1998) Flux of biogenic carbon in oceans: size-dependent regulation by pelagic food webs. Mar Ecol Prog Ser 164:1-11

Legendre L, Rassoulzadegan F (1995) Plankton and nutrient dynamics in marine waters. Ophelia 41:153-172

Legendre L, Rivkin RB (2002) Fluxes of carbon in the upper ocean: regulation by food-web control nodes. Mar Ecol Prog Ser 242:95-109

Legendre L, Rivkin RB (2005) Integrating functional biodiversity, food-web processes and biogeochemical carbon fluxes into a conceptual approach for modeling the upper ocean in a high- $\mathrm{CO}_{2}$ world. J Geophys Res 110:C09S17.1C09S17.17

> Lindeman RL (1941) Seasonal food-cycle dynamics in a senescent lake. Am Midl Nat 26:636-673

Lindeman RL (1942) The trophic-dynamic aspect of ecology. Ecology 23:399-418

Malmstrom RR, Kiene RP, Kirchman DL (2004) Identification and enumeration of bacteria assimilating dimethylsulfoniopropionate (DMSP) in the North Atlantic and Gulf of Mexico. Limnol Oceanogr 49:597-606

Marchant HJ, Scott FJ (1993) Uptake of sub-micrometer particles and dissolved organic matter by Antarctic choanoflagellates. Mar Ecol Prog Ser 92:59-64

Mari X, Dam HG (2004) Production, concentration, and isolation of transparent exopolymeric particles using paramagnetic functionalized microspheres. Limnol Oceanogr Methods 2:13-24

Martiny JBH, Bohannan B, Brown J, Colwell R and others (2006) Microbial biogeography: putting microorganisms on the map. Nat Rev Microbiol 4:102-112

> Middelboe M, Riemann L, Steward GF, Hansen V, Nybroe O (2003) Virus-induced transfer of organic carbon between marine bacteria in a model community. Aquat Microb Ecol $33: 1-10$

Mitra A, Flynn KJ (2005) Predator-prey interactions: Is 'ecological stoichiometry' sufficient when good food goes bad? J Plankton Res 27:393-399

Moloney CL, Field JG (1991) The size-based dynamics of plankton food webs. 1. A simulation model of carbon and nitrogen flows. J Plankton Res 13:1003-1038

- Moran MA, Miller WL (2007) Resourceful heterotrophs make the most of light in the coastal ocean. Natl Rev 5: 792-800

Moran MA, Zepp RG (1997) Role of photoreactions in the formation of biologically labile compounds from dissolved organic matter. Limnol Oceanogr 42:1307-1316

> Mousseau L, Klein B, Legendre L, Dauchez S, Tamigneaux E, Tremblay JE, Ingram RG (2001) Assessing the trophic pathways that dominate planktonic food webs: an approach based on simple ecological ratios. J Plankton Res 23: 765-777

Nagata T (2000) Production mechanisms of dissolved organic matter. In: Kirchman DL (ed) Microbial ecology of the oceans. Wiley-Liss, New York, p 121-152

Ogawa H, Amagai Y, Koike I, Kaiser K, Benner R (2001) Production of refractory dissolved organic matter by bacteria. Science 292:917-920

> Pace ML, Glasser JE, Pomeroy LR (1984) A simulation analysis of continental shelf food webs. Mar Biol 82:47-63

> Pernthaler J, Amann R (2005) Fate of heterotrophic microbes in pelagic habitats: focus on populations. Microbiol Mol Biol Rev 69:440-461 
Pomeroy LR (1974) The ocean's food web, a changing paradigm. Bioscience 24:499-504

Pomeroy LR, Wiebe WJ (1988) Energetics of microbial food webs. Hydrobiologia 159:7-18

Reinthaler T, Winter C, Herndl GJ (2005) Relationship between bacterioplankton richness, respiration, and production in the southern North Sea. Appl Environ Microbiol 71: 2260-2266

Richardson TL, Jackson GA (2007) Small phytoplankton and carbon export from the surface ocean. Science 315: 838-840

Rivkin RB, Legendre L (2001) Biogenic carbon cycling in the upper ocean: effects of microbial respiration. Science 291: $2398-2400$

Rivkin RB, Legendre L (2002) Roles of food-web and heterotrophic microbial processes in upper ocean biogeochemistry: global patterns and processes. Ecol Res 17:151-159

Robinson C, Williams P (2005) Respiration and its measurement in surface marine waters. In: del Giorgio PA, Paul A, Williams PJLeB (eds) Respiration in aquatic ecosystems. Oxford University Press, p 147-180

Ryther JH (1969) Photosynthesis and fish production in the sea. Science 166:72-76

Sherr EB, Sherr BF (1988) Role of microbes in pelagic food webs: a revised concept. Limnol Oceanogr 33:1225-1227

Sherr EB, Sherr BF (1994) Bacterivory and herbivory: key roles of phagotrophic protists in pelagic food webs. Microb Ecol 28:223-235

Sherr EB, Sherr BF (1996) Temporal offset in oceanic production and respiration processes implied by seasonal changes in atmospheric oxygen: the role of heterotrophic microbes. Aquat Microb Ecol 11:91-100

Sherr EB, Sherr BF (2008a) Understanding roles of microbes in marine pelagic food webs: a brief history. In: Kirchman DL (ed) Microbial ecology of the oceans, 2nd edn. Wiley, New York (in press)

Sherr EB, Sherr BF (2008b) Heterotrophic dinoflagellates: a significant component of microzooplankton biomass and major grazers of diatoms in the sea. Mar Ecol Prog Ser 352: 187-197

Sieburth JMcN, Smetacek V, Lenz J (1978) Pelagic ecosystem structure: heterotrophic compartments of plankton and their relationship to plankton size fractions. Limnol Oceanogr 33:1225-1227

Smith DC, Simon M, Alldredge AL, Azam F (1992) Intense hydrolytic enzyme activity on marine aggregates and implications for rapid particle dissolution. Nature 359: 130-142

Sobczak WV (2005) Lindeman's trophic-dynamic aspect of ecology: 'will you still need me when I'm 64?' Limnol Oceanogr Bull 14:53-57

Sorokin YI (1981) Microheterotrophic organisms in marine ecosystems. In: Longhurst AR (ed) Analysis of marine ecosystems. Academic Press, London, p 293-342

Stoecker DK, Michaels AE, Davis LH (1987) Large proportion of marine planktonic ciliates found to contain functional chloroplasts. Nature 326:790-792

Stoecker DK, Taniguchi A, Michaels AE (1989) Abundance of

Editorial responsibility: Peter Verity,

Savannah, Georgia, USA autotrophic, mixotrophic and heterotrophic planktonic ciliates in shelf and slope waters. Mar Ecol Prog Ser 50: 241-254

Straile D (1997) Gross growth efficiencies of protozoan and metazoan zooplankton and their dependence on food concentration, predator-prey weight ratio, and taxonomic group. Limnol Oceanogr 42:1375-1385

Strayer D (1988) On the limits to secondary production. Limnol Oceanogr 33:1217-1220

Strom SL, Benner R, Ziegler S (1997) Planktonic grazers are a potentially important source of marine dissolved organic carbon. Limnol Oceanogr 42:1364-1374

Suttle CA (1994) The significance of viruses to mortality in aquatic microbial communities. Microb Ecol 28:237-243

Suttle CA (2005) Viruses in the sea. Nature 437:356-361

Suttle CA (2007) Marine viruses - major players in the global ecosystem. Natl Rev 5:801-812

Teira E, Vanaken H, Veth C, Herndl GJ (2006) Archaeal uptake of enantiomeric amino acids in the meso- and bathypelagic waters of the North Atlantic. Limnol Oceanogr 51:60-69

Thingstad TF, Lignell R (1997) Theoretical models for the control of bacterial growth rate, abundance, diversity and carbon demand. Aquat Microb Ecol 13:19-27

> Tranvik LJ, Sherr EB, Sherr BF (1993) Uptake and utilization of colloidal DOM by heterotrophic flagellates in seawater. Mar Ecol Prog Ser 92:301-309

Tremblay JE, Klein B, Legendre L, Rivkin RB, Therriault JC (1997) Estimation of $f$-ratios in oceans based on phytoplankton size structure. Limnol Oceanogr 42:595-601

Troost TA, Kooi BW, Kooijman SA (2005) Ecological specialization of mixotrophic plankton in a mixed water column. Am Nat 166:E45-E61

Unanue M, Azúa I, Arrieta JM, Labirua-Iturburu A, Egea L, Iriberri J (1998) Bacterial colonization and ectoenzymatic activity in phytoplankton-derived model particles: cleavage of peptides and uptake of amino acids. Microb Ecol 35:136-146

Urban-Rich JL (1997) Latitudinal variations in the contribution by copepod fecal pellets to organic carbon and amino acid flux. PhD thesis, University of Maryland, College Park

Urban-Rich J (1999) Released of dissolved organic carbon from copepod fecal pellets in the Greenland Sea. J Exp Mar Biol Ecol 232:107-124

Verdugo P, Alldredge AL, Azam F, Kirchman DL, Passow U, Santschi PH (2004) The oceanic gel phase: a bridge in the DOM-POM continuum. Mar Chem 92:67-85

Vinogradov ME, Menshutkin VV, Shushkina EA (1972) On mathematical simulation of a pelagic ecosystem in tropical waters of ocean. Mar Biol 16:261-268

Wilhelm SW, Suttle CA (1999) Viruses and nutrient cycles in the sea. Bioscience 49:781-788

Williams PJleB (1981) Incorporation of microheterotrophic processes into the classical paradigm of the planktonic food web. Kieler Meeresforsch 5:1-28

ZoBell CE (1946) Marine microbiology: a monograph on hydrobacteriology. Chronica Botanica, Waltham, MA

Submitted: July 20, 2007; Accepted: March 4, 2008

Proofs received from author(s): July 21, 2008 